\title{
Microwave Technology Using Low Energy Concentrated Beam for Processing of Solid Waste Materials from Rapana thomasiana Seashells
}

\author{
Sorin Vasile Savu ${ }^{1, *(\mathbb{D}}$, Daniela Tarnita ${ }^{2, *(\mathbb{D}}$, Gabriel Constantin Benga ${ }^{1}$, Ilie Dumitru ${ }^{3}$, Iulian Stefan ${ }^{1} \mathbb{D}$, \\ Nicolae Craciunoiu ${ }^{3}$, Adrian Bebe Olei ${ }^{1}$ and Ionel Danut Savu ${ }^{1}$
}

1 Department of Engineering and Management of Technological Systems, University of Craiova, 1 Calugareni Str., 220037 Drobeta-Turnu Severin, Romania; gabriel.benga@edu.ucv.ro (G.C.B.); iulian.stefan@edu.ucv.ro (I.S.); bebe.olei@edu.ucv.ro (A.B.O.); ionel.savu@edu.ucv.ro (I.D.S.)

2 Department of Applied Mechanics, University of Craiova, 107 Calea Bucuresti Str., 200512 Craiova, Romania

3 Department of Automotive, Transport and Industrial Engineering, University of Craiova, 200585 Craiova, Romania; dumitru_ilie@yahoo.com (I.D.); ncraciunoiu@yahoo.com (N.C.)

* Correspondence: sorin.savu@edu.ucv.ro (S.V.S.); daniela.tarnita@edu.ucv.ro (D.T.); Tel.: +40-722691192 (S.V.S.); +40-722292228 (D.T.)

\section{check for}

updates

Citation: Savu, S.V.; Tarnita, D.; Benga, G.C.; Dumitru, I.; Stefan, I.; Craciunoiu, N.; Olei, A.B.; Savu, I.D. Microwave Technology Using Low Energy Concentrated Beam for Processing of Solid Waste Materials from Rapana thomasiana Seashells. Energies 2021, 14, 6780. https:// doi.org/10.3390/en14206780

Academic Editors: Gheorghe Voicu and Gigel Paraschiv

Received: 30 August 2021

Accepted: 13 October 2021

Published: 18 October 202

Publisher's Note: MDPI stays neutral with regard to jurisdictional claims in published maps and institutional affiliations.

Copyright: (c) 2021 by the authors. Licensee MDPI, Basel, Switzerland. This article is an open access article distributed under the terms and conditions of the Creative Commons Attribution (CC BY) license (https:// creativecommons.org/licenses/by/ $4.0 /)$.
Abstract: The solid waste of Rapana thomasiana seashells both from domestic activities and natural waste on seashore can be used to obtain viable products for medical applications. However, conventional technologies applied for sintering the materials require massive energy consumption due to the resistance heating. Microwave heating represents an advanced technology for sintering, but the stability of the process, in terms of thermal runaway and microwave plasma arc discharge, jeopardizes the quality of the sintered products. This paper aims to present the results of research focused on viable heating technology and the mechanical properties of the final products. A comparative analysis, in terms of energy efficiency vs. mechanical properties, has been performed for three different heating technologies: direct microwave heating, hybrid microwave heating and resistance heating. The results obtained concluded that the hybrid microwave heating led to final products from Rapana thomasiana solid waste with similar mechanical properties compared with resistance heating. In terms of energy efficiency, the hybrid microwave heating was 20 times better than resistance heating.

Keywords: Rapana thomasiana solid waste; microwave heating; energy efficiency

\section{Introduction}

The waters of the seas and oceans cover about $70 \%$ of the earth's surface [1], and the approximately 2.2 million different marine species occupy $90-95 \%$ of the biosphere by volume of living organisms [1,2]. In recent years, there have been numerous modern tools and methodologies in biotechnology designed to explore better marine derivatives that can be implemented in both the medical and non-medical fields [3]. States in the European community, as well as USA, Japan, China, Korea and Russia, consider achievements in marine biotechnology as a fundamental part of their economy, in which they invested more than USD 693.9 billion in 1995, in new facilities/equipment [4]. The world market for pharmaceuticals was valued at USD 643 billion in 2006 [5], while enzymes extracted from marine biosources were valued at USD 50 billion a year. The annual profits obtained from cancer-fighting agents derived from marine sources in 2005 were about USD 1 billion [5]. Total sales of AIDS drugs worldwide were estimated to be about USD 4 billion in 2005. The value of the cosmetics industry in 2005 was USD 231 billion. The world market for skincare products was valued at USD 38.3 billion globally in 2005 [5]. Marine-derived materials based on marine biosources have been used as raw materials for bioengineering or as basic elements for research and biomimetic products [6-8]. 
The remains of fish, shellfish and snails and marine crustaceans are a major source of waste in the fisheries and aquaculture sectors, much of this waste being disposed of at sea. The impact on the environment of the elimination of these discharges into the ocean has effects that are harmful to aquatic life, including decreased marine oxygen levels, nutrient imbalances and pronounced turbidity [9]. Various papers have studied the environmental benefits of reusing shell waste [10], such as oysters [11] and shells [12]. Current research focuses mainly on the isolation of different nutrient flows from waste [9,13-15], but there are some papers, fewer in number, that have studied other marine derivatives, such as epoxy composites [16], biocomposites [17] or organic adsorbents, such as snail shell, used mainly to remove contaminants from wastewater [18-20].

Chitin (CT) and its derivative, chitosan (CS), a basic polysaccharide, can be obtained from marine sources, such as algae, crustaceans, insects or invertebrate animals such as octopus, cuttlefish, snails and squid [21,22]. Globally, the CT and CS derivatives market was valued at USD 2.9 billion in 2017, with an annual growth rate of $14.8 \%$ and, by 2024 , estimates lead to an increase of up to USD 63 billion [23]. The two products obtained from marine sources have very important properties such as biocompatibility, non-toxicity, molecular adsorption and versatility, which make them extremely attractive in various medical and non-medical fields, such as: textile; food; photography; medical, pharmaceutical and environmental applications [24-28]; pharmacology [29]; food systems [30]; and cosmetology [31].

Humans have consumed snails since prehistoric times [32]. Regarding the export of snails, countries such as Morocco, Romania and Bulgaria were in first place $[33,34]$. The world market for edible snails amounts to 300,000 tons, worth EUR 1 billion. Of the total quantity, 100,000 tons are consumed in the EU, which represents only about $60-70 \%$ of their demand [35]. Due to their properties, snail shells and shells are a very good source for synthesizing bioactive and biocompatible biomaterials usable in the human body [36].

Originally from the waters of the Asian Pacific, Rapana thomasiana (RT) is an invasive alien species in the Black Sea [37,38]. In 1942 it was first recorded in the Black Sea. In a very short time, it spread along the Caucasus coasts, the Sea of Azov [39,40], the Marmara Sea, the Aegean Sea, the Adriatic Sea, the Mediterranean Sea, the United States (east coast) [41] and Brazil (south coast) [42]. RT fishing mainly uses the dredging method, in addition to methods such as scuba diving. The percentages for using this destructive fishing method that causes damage to small benthic organisms are over 95\% in Bulgaria and Turkey, 90\% in Ukraine and 74\% in Romania [43]. Although the global impact of RT is negative from an ecological, social and economic point of view, it has been suggested to be "sustainable" for the Black Sea, according to reports on the state of the RT stock in the Black Sea $[44,45]$. RT is the only invasive Black Sea species with a valuable commercial stock. Exports of RT fished from the Black Sea reached USD 12.5 million in 2017 [37]. RT has been commercially exploited in Romania since 2010 in the food industry, collected from the Black Sea coast or from the fishing sector $[46,47]$. The main advantages of using RT are the very high $\mathrm{CaCO}_{3}$ content (95-99\% by weight) and the mechanical properties similar to hard tissues, such as human bones, and the low cost of production [48]. As a result, RT shells can be used as a natural source of calcium for the synthesis of biomaterials with applications in bone tissue engineering (TE) [49].

In recent decades, various techniques such as bone grafting [50] or prosthesis [51-57] have been used to regenerate bone defects caused by trauma, osteoarthritis, osteoporosis, tumors, etc., but harmful immune responses and insufficient donor tissues are serious disadvantages for the application of these techniques [58-60]. In recent years, marine biocomposites, having as sources: corals, fish bone, sponges, shells and snail shells have become a very promising material used in the field of TE [61-64].

Hydroxyapatite (HAp) is the most important bioceramic material for bone TE due to extremely important properties such as biocompatibility, bioactivity and stability, biological properties necessary for rapid bone regeneration [7,8,65-67]. HAp has several marine biological sources, such as cuttlefish bone [68], corals [69], fish bones [70,71] and 
shells [72,73], which provide cheap raw materials. Concerns about reducing environmental pollution by disposing of waste and achieving value-added production have led to research on the production of HAp in seashells and fish bones [8-10]. For good performance in the successful use of HAp in bone grafts, an adequate pore size and shape is required [74].

Calcium phosphates $(\mathrm{CaP})$ and HAp grafts can be obtained from biomarine sources by various methods and techniques, [75,76], which include: thermal calcination method [77], hydrothermal method [78], precipitation method [79], ultrasonic precipitation [79], combustion solution [80], microwave [80], emulsion [81], sol-gel [78], calcined polymer-assisted methods, hydrolysis [82] and polymer-based method [83,84]. The most used techniques for the production of HAp powders are: the hydrothermal method, based on a mixture of di-ammonium hydrogen phosphate and $\mathrm{CaCO}_{3}$ at high pressures of $82.73 \mathrm{MPa}$ and temperatures reaching $275^{\circ} \mathrm{C}$, as well as wet chemical precipitation methods. Compared to other shells, the snail and shell shells, containing about $95-97 \% \mathrm{CaCO}_{3}$, are characterized by high mechanical strength. They are collected, boiled in water and washed thoroughly to remove impurities, and then the samples are sprayed into powders of the required size.

Regarding the durability of the processing pathway, a study conducted in [75] shows that, as a rule, natural sources require calcination at a certain temperature to obtain HAp with properties similar to human bone apatite, while synthetic chemical sources involve the use of carefully controlled chemicals and stoichiometric reactions to synthesize HAp with the necessary characteristics. At the same time, natural sources of HAp have proven to be more economically viable and more advantageous compared to synthetic sources [75], because natural sources are, in most cases, residual products of other human activities (for example, the food industry), which are generally obtained at no cost or at very low cost [75].

This paper aims to study the introduction of microwave technology for sintering the RT powders obtained through milling from domestic solid waste. The research has been performed in order to prove the performance of the process, in terms of energy consumption, for products with similar or better mechanical properties of sintered products.

The research was oriented to obtain new products from RT seashells solid waste by applying two sintering technologies: the first technology was microwave sintering, consisting of direct microwave sintering and hybrid microwave sintering; the second technology was conventional sintering using an experimental oven with electrical resistance. In the case of powders obtained from domestic or natural solid residues based on RT seashells, according to the literature $[49,85]$ they are susceptible to microwaves and can be heated for sintering, thus obtaining new products for biomedical applications and more. However, effects such as thermal runaway or the appearance of the microwave plasma arc, which can lead to the destruction of samples or even the microwave generator, often limit pure microwave sintering technology. The main advantage of microwave heating consists of fast heating of ceramic materials that leads to reduced sintering time. Therefore, the size of the grain will be maintained at low dimensions. In addition, energy consumption plays an important role in industry and by applying microwave heating, the carbon footprint is low. Microwave heating, through low consumption in terms of energy, contributes to sustainable development compared with conventional heating in resistance or induction ovens.

\section{Materials and Methods}

\subsection{Materials}

The materials used for the experimental microwave sintering were powders obtained by mechanical milling from RT seashells using a planetary ball mill type Pulverisette 4 (FRITSCH GmbH-Milling and Sizing, 2006, Germany). The applied milling procedure specified $4 \mathrm{~h}$ at $400 \mathrm{rot} / \mathrm{min}$ speed, starting from chips of seashells preliminarily milled to max $0.5 \mathrm{~mm}$ dimensions. The size of powders was measured using Nanosight LM10 nanosizer (Malvern Panalytical Ltd., 2007, United Kingdom), and the measurements revealed dimensions below $2000 \mathrm{~nm}$, with a peak at $1462.6 \mathrm{~nm}$ (see Figure 1). 


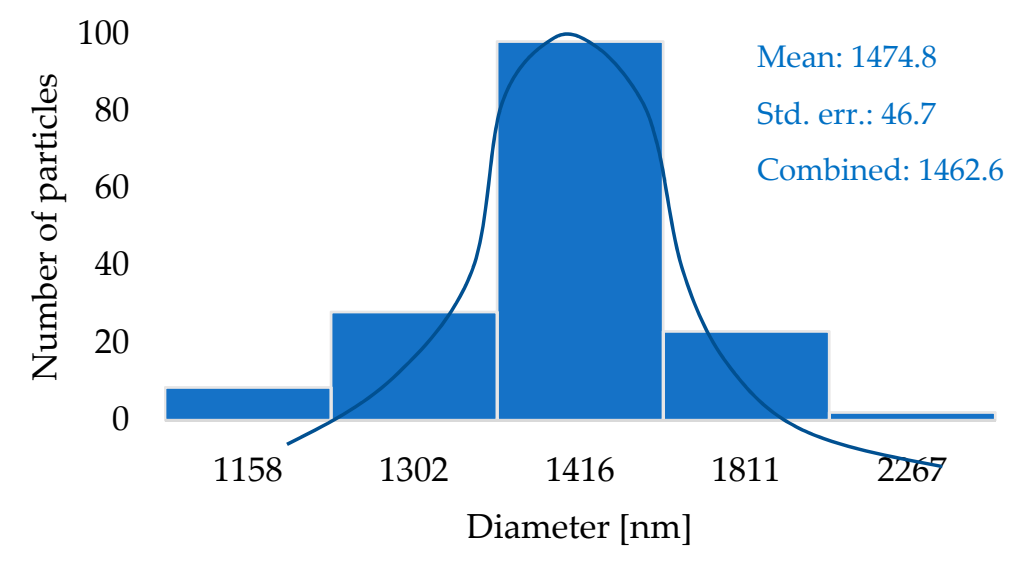

Figure 1. Grain size distribution of the RT powder (Malvern nanosizer).

After the milling, samples of RT powder were investigated to reveal the chemical composition by using emission spectrometry. The investigation was conducted by using specific equipment, Agilent 725 ICP-OES from Agilent Technologies (Agilent, 2019, USA). A second analysis of the powder, performed in conjunction with the ICP-OES, was the identification of the crystalline phases that are present in the RT powder. Quantax 80 of Bruker (Bruker $\mathrm{GmbH}$, Germany) was used for EDX analysis (Figure 2 shows the identified elements beside the $\mathrm{CaCO}_{3}$ that was evaluated to about $94.8 \%$ of the total material-EDX, please see the Figure 2).

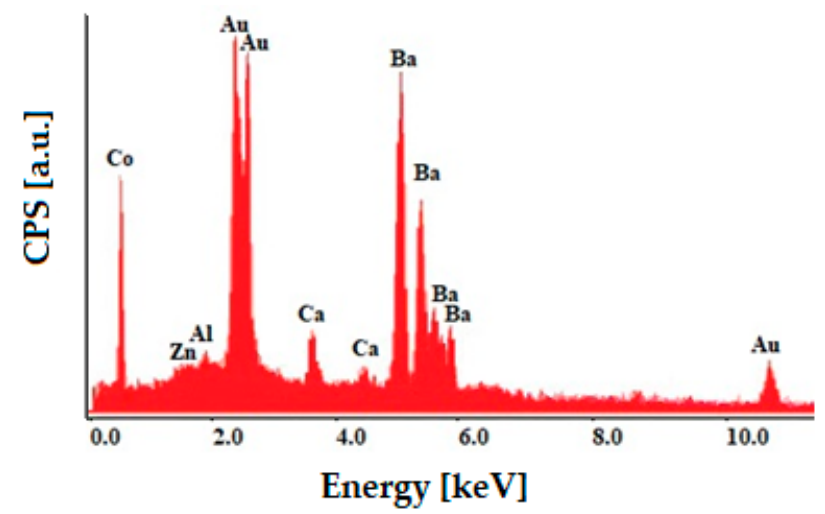

Figure 2. Chemical elements identified by EDX analysis.

The powders were pressed using LBG-10 Universal Testing Machine of RMU testing equipment (LBG testing equipment srl, 2010, Italy) at $559 \mathrm{MPa}$ and a dye with inner diameter equal to $15 \mathrm{~mm}$. In order to avoid the loss of consistency, the samples were doped with $2 \% \mathrm{Zn}$ stearate. Figure 3 below presents the compaction process and the Table 1 below presents the results obtained for RT samples.

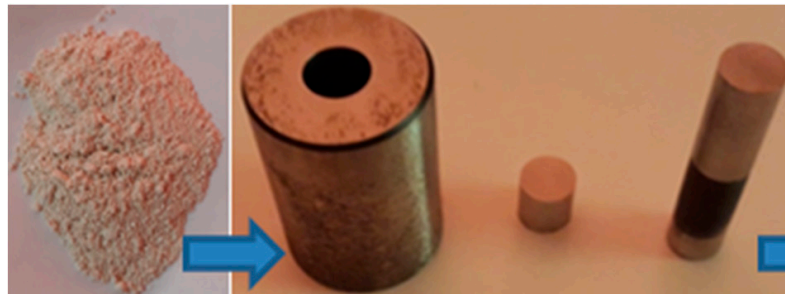

(a) (b)

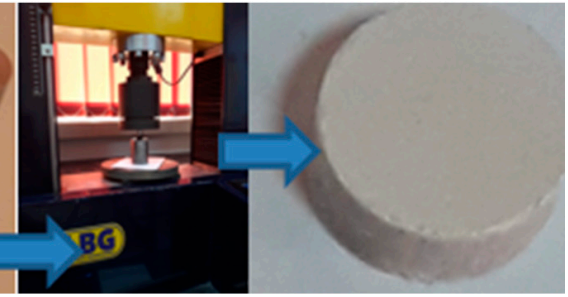

(c) (d)

Figure 3. RT samples from seashell powders: (a) seashell waste milled and homogenized in planetary ball mill Pulverisette 4, (b) dye, (c) LBG 10 kN Universal Testing Machine, (d) RT samples. 
Table 1. Properties of the RT samples.

\begin{tabular}{cccc}
\hline Sample & Diameter $[\mathbf{m m}]$ & Height $[\mathrm{mm}]$ & Weight $[\mathrm{g}]$ \\
\hline RT-P1 & 15.21 & 5.81 & 1.988 \\
RT-P2 & 15.24 & 5.49 & 2.051 \\
RP-P3 & 15.29 & 3.92 & 1.528 \\
RT-P4 & 15.27 & 3.71 & 1.532 \\
RT-P5 & 15.28 & 3.66 & 1.523 \\
RT-P6 & 15.28 & 3.63 & 1.512 \\
RT-P7 & 15.25 & 3.74 & 1.534 \\
RT-P8 & 15.26 & 3.68 & 1.535 \\
RT-P9 & 15.23 & 3.64 & 1.525 \\
\hline
\end{tabular}

The weight of RT samples was measured using an analytical balance type WPS 510/C / 2 produced by Partner LLC in 2007 having the following technical characteristics: error of measurement $0.01 \mathrm{~g}$ and precision of measurement $0.001 \mathrm{~g}$. The geometric dimensions of RT samples were measured using a digital caliper produced by PowerFix in 2011 with the following technical specifications: measurement range $0-150 \mathrm{~mm}$, resolution 0.01 and precision $0-100 \mathrm{~mm}+0.02$.

The microwave heating system (Muegge GmbH, MW Power Supply 6 kW/2450 MHz type MX6000D-154KG and Magnetron Head 6 kW/2450 MHz type MH6000S-250BF, 2020, Germany) consists of a Muegge microwave generator with a water-cooled magnetron having adjustable power between $600 \mathrm{~W}$ and $6000 \mathrm{~W}$. The microwave installation is connected to an automatic tuner matching impedance Tristan $6 \mathrm{~kW}$ controlled by Homer software (Muegge GmbH, Homer Autotuner ISM 2450 MHz, 2009, Germany). The autotuner helps the microwave generator to transfer the maximum power to the samples from the heating chamber. Temperature monitoring was performed using an Optris G5H type infrared pyrometer (Optris $\mathrm{GmbH}$, Optris CT Glass G5H, 2009, Germany) with a measuring range between $250^{\circ} \mathrm{C}$ and $1650{ }^{\circ} \mathrm{C}$ with a spectral range of $5 \mu \mathrm{m}$ and an optical resolution of 20:1. Figure 4 presents the microwave installation for sintering the RT powders.

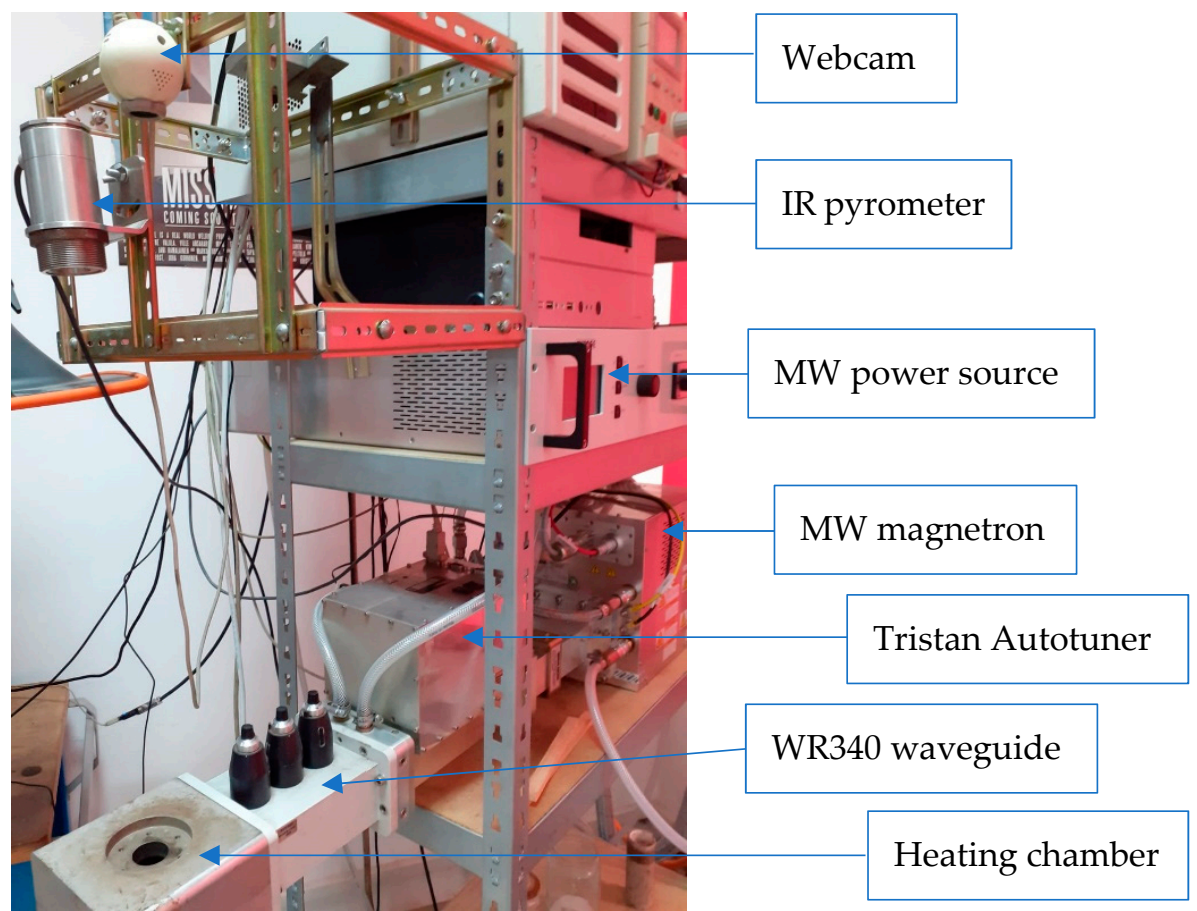

Figure 4. Microwave installation for sintering of RT powders. 
In order to avoid overheating the impedance tuner and implicitly gripping the stub tuners, an additional rectangular waveguide type WR340 was inserted between the sintering chamber and the waveguide of the autotuner together with a cooling flange with internal channel through which water circulates at the same pressure as in the microwave generator. The complementary cooling system contributes to the reduction of the heat inside the waveguide of the autotuner by up to $6{ }^{\circ} \mathrm{C}$ at a continuous operation of more than $2 \mathrm{~h}$.

\subsection{Methodology}

2.2.1. Direct Microwave Heating of the Samples

Direct microwave heating aims to obtain sintering temperature by converting the microwave into heat inside the RT samples. This means that the injected power from the magnetron is converted into heat and the reflected power is maintained at low level. Based on scientific literature, the sintering process could be similar to the sintering of $\mathrm{CaCO}_{3}$, taking into consideration that RT samples have similar chemical composition. The heating regimes are presented in the Table 2 below.

Table 2. Heating parameters for direct microwave heating.

\begin{tabular}{ccc}
\hline Sample & MW Injected Power [W] & Sintering Time [min] \\
\hline RT-P1 & 600 & 30 \\
RT-P2 & 660 & 30 \\
RP-P3 & 720 & 10 \\
\hline
\end{tabular}

The RT samples were placed in the microwave heating chamber presented in Figure 5. In order to obtain best exposure of the samples to the direct microwave beam, the samples were lifted by $7 \mathrm{~mm}$ from the bottom of the heating chamber.

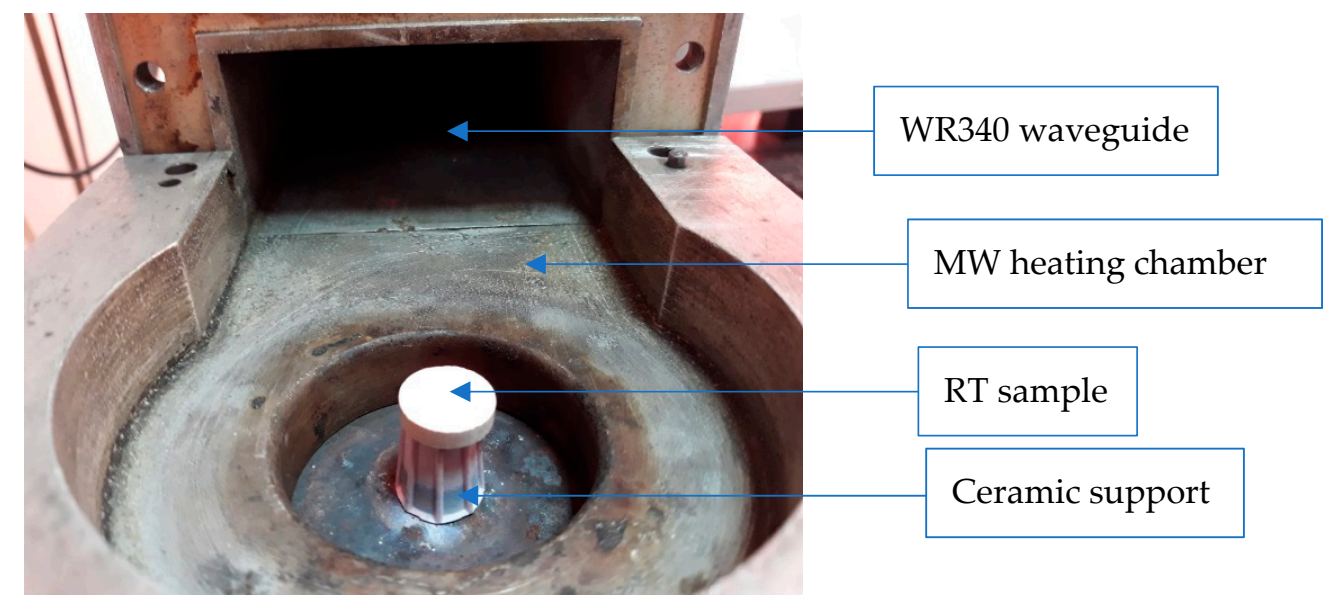

Figure 5. Conditions for direct microwave heating.

The ceramic support for RT samples does not absorb and convert microwaves into heat, being neutral to microwaves [86-88]. Due to low frequency of microwave generator, the coupling process in microwave heating does not dissipate the power in an efficient way at room temperature. The direct microwave heating process was stable until the temperature reached $900^{\circ} \mathrm{C}$. Beyond this temperature the microwave plasma arc occurred and the microwave generator stopped the process. The temperature evolution during direct microwave heating is presented in the Figure 6. The samples RT-P1 and RT-P2 were heated at $600 \mathrm{~W}$ and $660 \mathrm{~W}$ injected microwave power and the process was stable. Both the temperature increase interval from the ambient temperature to the temperature of $750{ }^{\circ} \mathrm{C}$ for RT-P1 and $850{ }^{\circ} \mathrm{C}$ for RT-P2, respectively, and on the sintering temperature maintenance level was for $30 \mathrm{~min}$. In the case of the RT-P3 sample, the power injected by 
the microwave generator was too high, compared to the ability of pressed powder from seashells to convert the microwaves to heat. Therefore, the appearance of the microwave plasma arc suspended the sintering process due to the automatic disconnection of the microwave generator.

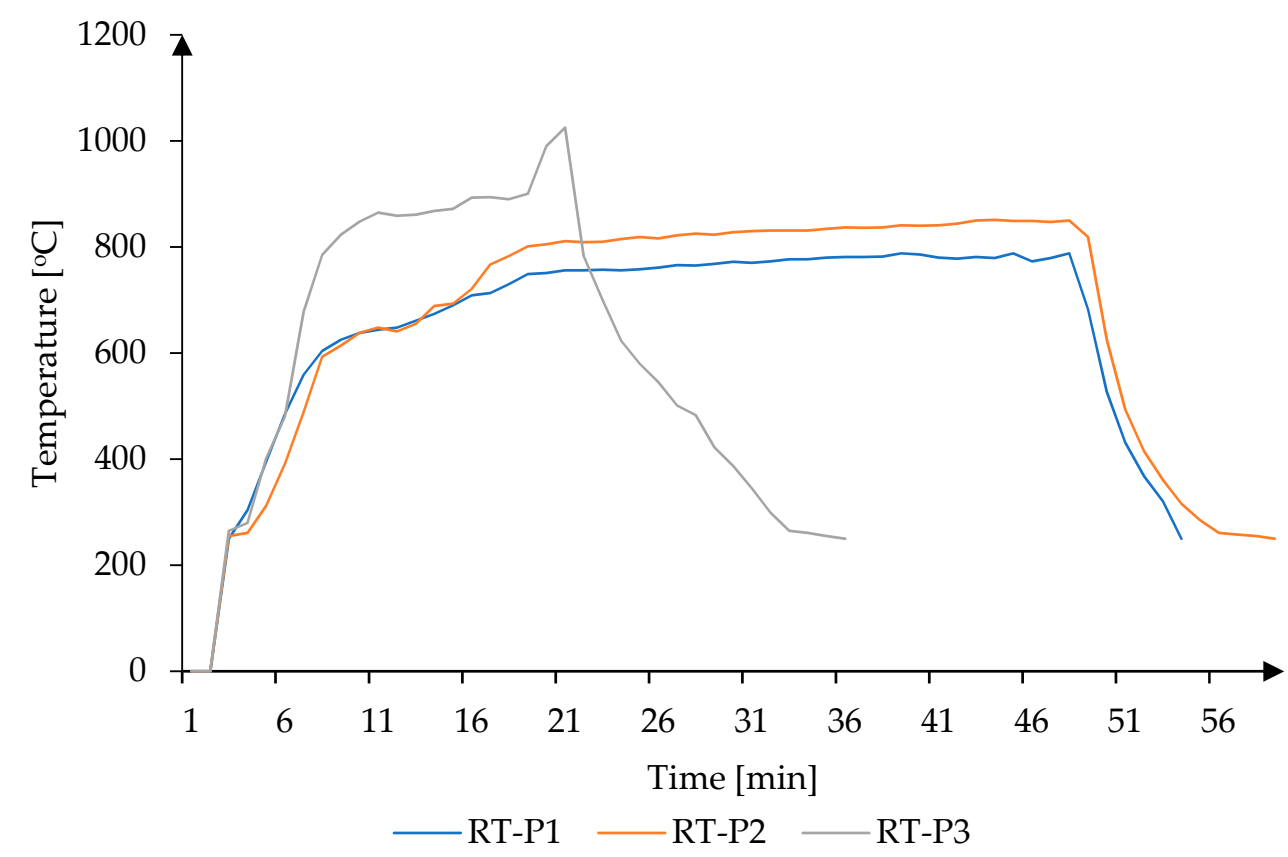

Figure 6. Temperatures in direct microwave heating.

It can be seen from the graph above that there is a sudden rise in temperature above the value of $1000^{\circ} \mathrm{C}$, which was recorded by the pyrometer with infrared radiation, followed by a sudden decrease and a natural cooling. In terms of optimization of the direct microwave heating process, the calculation of the minimum impedance of electrical circuit and maximization of transferred power from microwave generator to RT samples has led to the following balance power chart (see Figure 7a,b).

According to the Smith chart and power distribution in the microwave heating process, the total injected power was calculated as $597.30 \mathrm{~W}$, the reflected power was $56.39 \mathrm{~mW}$ and the absorbed power was $597.24 \mathrm{~W}$.

The performance of the generating/conversion process was $99.98 \%$. This performance of the process could be achieved because of establishing a resonant circuit by using the three stub tuners. The position of the screws of stub tuners in waveguide was calculated to the following values: $\mathrm{s}_{1}=0 \mathrm{~mm}, \mathrm{~s}_{2}=18.44 \mathrm{~mm}$ and $\mathrm{s}_{3}=16.98 \mathrm{~mm}$ considering position 1 $\left(\mathrm{s}_{1}\right)$ as being the closest to microwave generator.

\subsubsection{Hybrid Microwave Heating of the Samples}

Taking into consideration the occurrence of microwave arc discharge for microwave powers above $700 \mathrm{~W}$, the sintering process was researched using hybrid heating. The microwave hybrid heating consists of using a ceramic crucible (see Figure $8 \mathrm{a}, \mathrm{b}$ ) with high absorbance and conversion of microwave into heat properties, which helps the RT samples to reach sintering temperature. Before starting the hybrid microwave heating process, a simulation of temperature evolution in the samples placed in the ceramic crucible was performed. The simulation was required in order to determine to what extent the heat produced by the ceramic crucible would contribute to the achievement of the sintering temperature of RT samples. 


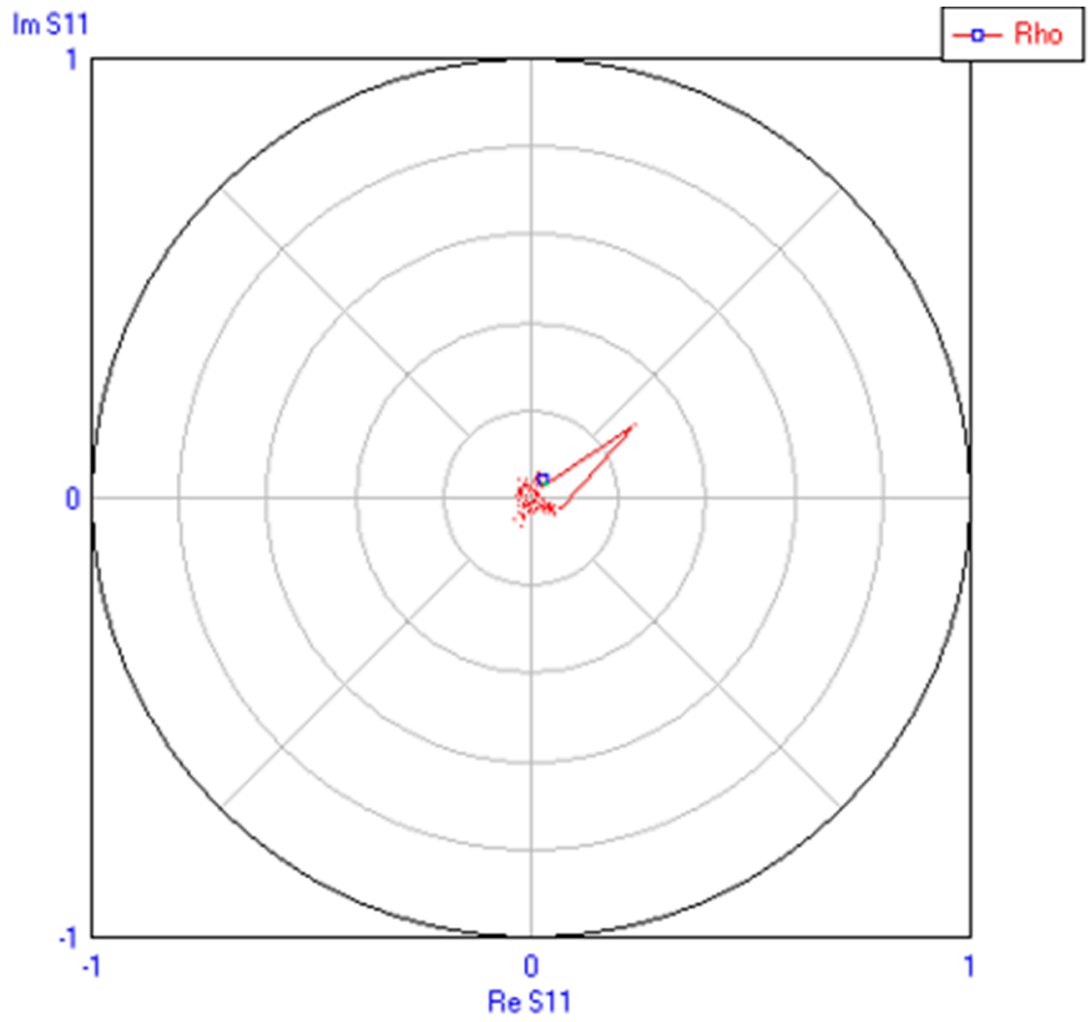

(a)

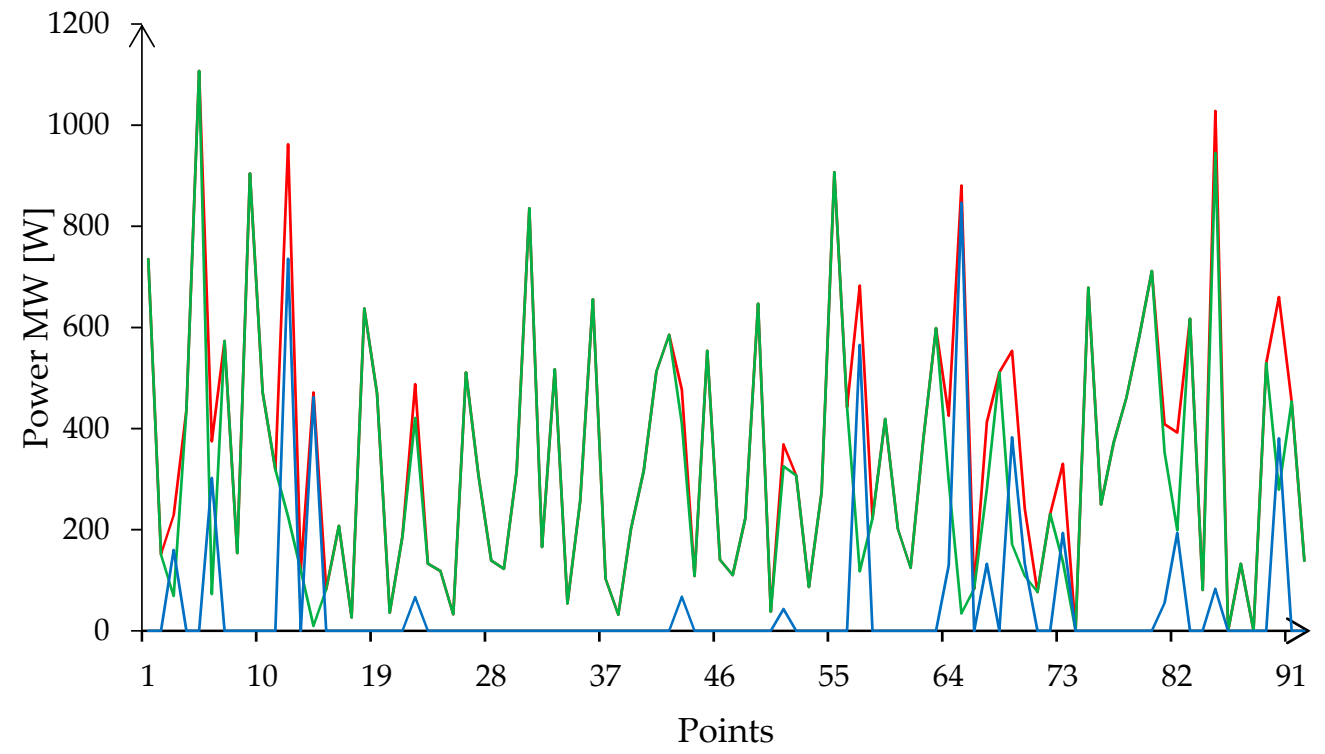

- Pinc $[W] \longrightarrow$ Pabs $[W] \quad$ Pref $[W]$

(b)

Figure 7. Optimization of heating process by reduction of the loss energy: (a) Smith chart-matching load impedance, $(\mathbf{b})$ power balance in microwave heating process. 


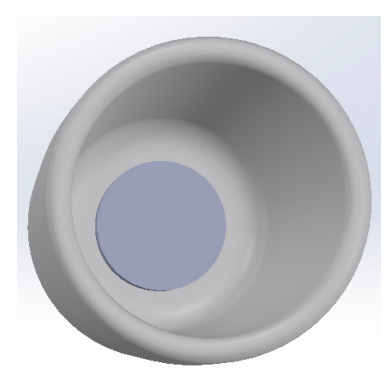

(a)

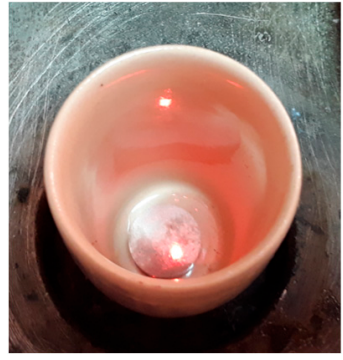

(b)

Figure 8. Initial parameters for simulation of the heat transfer: (a) simulated ceramic porcelain crucible, (b) real ceramic porcelain crucible placed in heating chamber.

The theoretical approach of the simulation of the thermal field started from the equations of heat transfer in solid materials $[49,87]$.

$$
\rho \cdot C_{p} \cdot \frac{\delta T}{\delta t}-\nabla \cdot(\mathrm{k} \nabla \mathrm{T})=\mathrm{Q}
$$

where $\rho=2.3-2.4 \mathrm{~g} / \mathrm{cm}^{3}$ representing the density of ceramic porcelain, $C_{p}=877.96 \mathrm{~J} / \mathrm{KgK}$ is the specific heat at constant pressure and $\mathrm{k}=1.4949 \mathrm{~W} / \mathrm{mK}$ represents a property for heat conductivity of the ceramic porcelain [89-91]. The heat flux boundary condition is given by the following equation:

$$
-n \cdot(-\mathrm{k} \nabla \mathrm{T})=\mathrm{h} \cdot\left(T_{R T}-T_{C P C}\right)
$$

where $T_{R T}=25{ }^{\circ} \mathrm{C}$, representing the temperature of RT samples without heat transfer, $T_{C P C}=1500{ }^{\circ} \mathrm{C}$, representing the maximum temperature developed through conversion of microwave into heat for $1200 \mathrm{~W}$ injected microwave power. The simulation process started with determination of the hottest point obtained on the ceramic porcelain crucible walls (see the Figure 9). The heating process was performed without RT samples placed inside the crucible and it was stopped when the crucible started to melt or the plasma arc occurred [86].

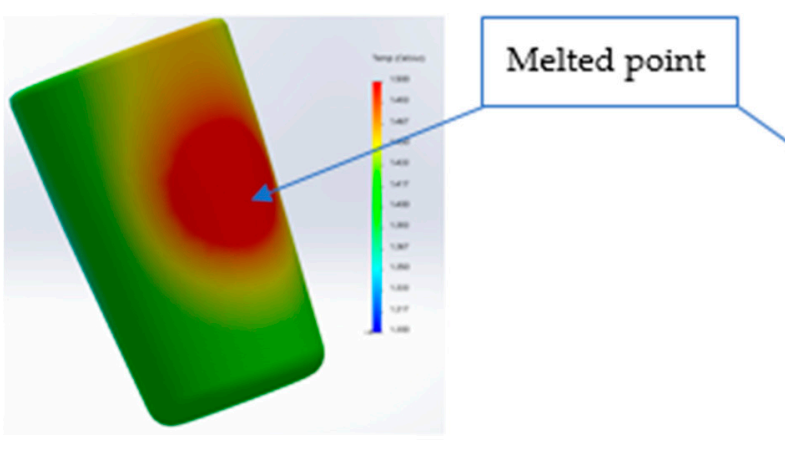

(a)

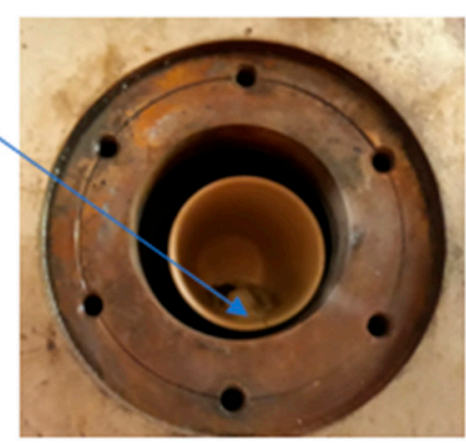

(b)

Figure 9. Determination of melting point as boundary conditions for simulation: (a) maximum temperature allowed for process simulation, (b) snapshot after real microwave heating of ceramic porcelain crucible.

The heating process started with $600 \mathrm{~W}$ injected power from the microwave generator. The temperature increased at $160{ }^{\circ} \mathrm{C} / \mathrm{min}$ until the temperature reached $636{ }^{\circ} \mathrm{C}$. The microwave power increased successively from $60 \mathrm{~W}$ up to $1140 \mathrm{~W}$ when the temperature increased to $1300{ }^{\circ} \mathrm{C}$. The process was stabilized for $2 \mathrm{~min}$ at $1300{ }^{\circ} \mathrm{C}$ and then the microwave power increased to $1300 \mathrm{~W}$. The temperature increased up to $1500{ }^{\circ} \mathrm{C}$. The ceramic porcelain crucible suffered a crack and a local overheating that led to the IR pyrometer 
being out of range. Using the data collected from real microwave heating of the ceramic porcelain crucible, the simulation of heat transfer was performed using a thermal module from Solidworks 2016 software (Dassault Systems, 2016). Using conduction heating and one iteration for the simulation starting with $1500{ }^{\circ} \mathrm{C}$, the simulation of the heat transfer to RT samples is presented in the Figure 10.

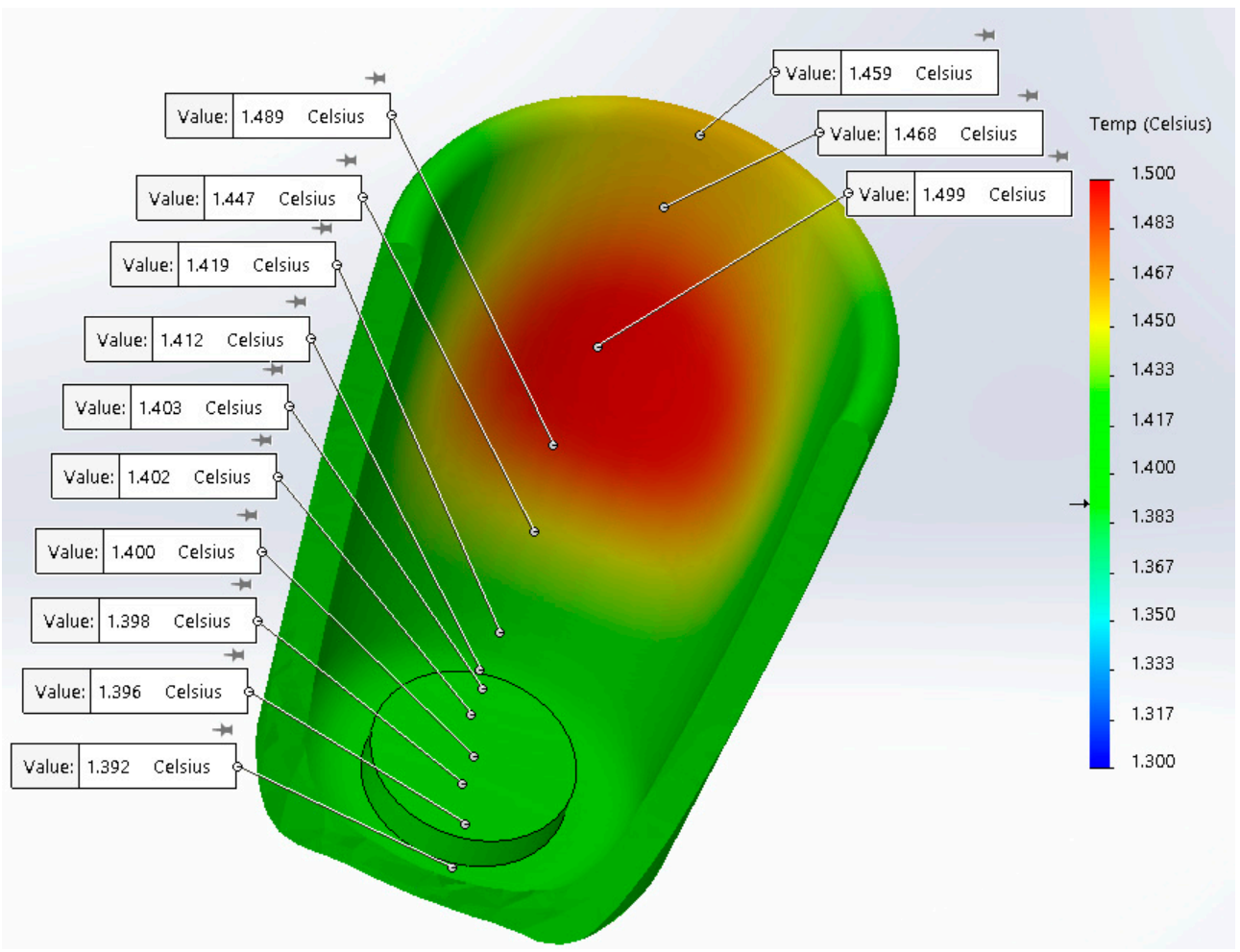

Figure 10. Simulation of the thermal transfer using conduction heating.

The results of the simulation showed that the temperature achieved on the bottom of the RT sample was $1392{ }^{\circ} \mathrm{C}$ and $1396^{\circ} \mathrm{C}$ on the top of the RT sample. By plotting 13 nodes on the crucible surface and RT sample, the distribution of the temperature can be appreciated as in the Figure 11.

Based on the simulation model, the hybrid heating process has been conducted for the samples codified from RT-P4 to RT-P8. The hybrid heating process has been applied following the same scenario as in the first three samples. The Table 3 and graphs of Figure 12 present the hybrid microwave heating regimes for RT samples and the temperature evolution. The weight of RT samples has been measured using an analytical balance (RADWAG WAGI ELEKTRONICZNE, model WPS 510/C/2, 2007, Poland), having the following technical characteristics: error of measurement $0.01 \mathrm{~g}$ and precision of measurement $0.001 \mathrm{~g}$. The geometric dimensions have been measured using a digital caliper (PowerFix, model HG00962A, 2011, United Kingdom) with the following technical specifications: measurement range $0-150 \mathrm{~mm}$, resolution 0.01 and precision $0-100 \mathrm{~mm} \pm 0.02$.

Table 3. Heating parameters for hybrid microwave heating.

\begin{tabular}{ccc}
\hline Sample & MW Injected Power [W] & Dwell Time [min] \\
\hline RT-P4 & 1320 & 30 \\
RT-P5 & 1200 & 30 \\
RT-P6 & 1140 & 120 \\
RT-P7 & 1560 & 10 \\
RT-P8 & 1200 & 10 \\
\hline
\end{tabular}




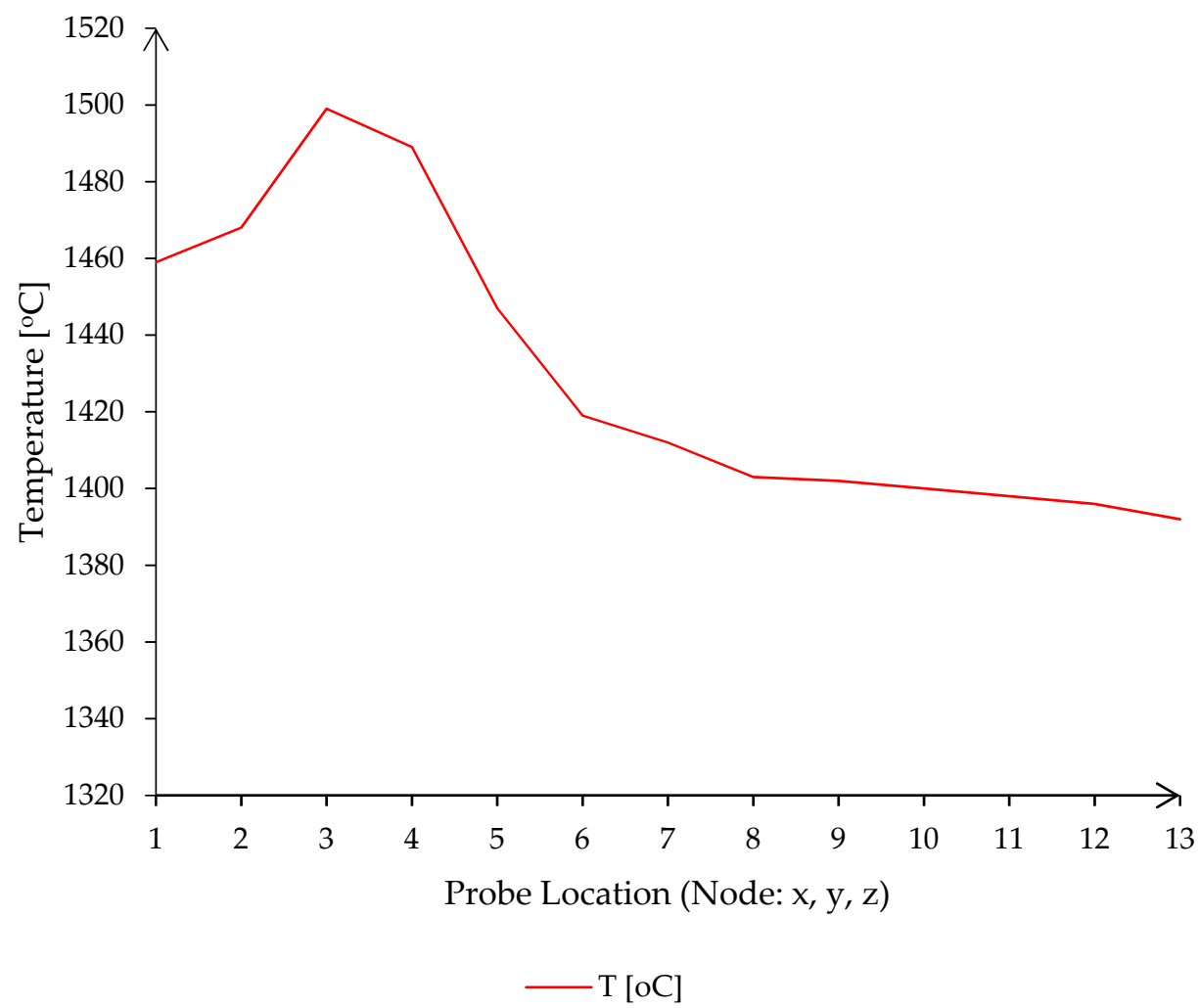

Figure 11. Temperature distribution according to simulation.

The Figure 12 presents the temperature evolution for different levels of microwaveinjected powers from magnetron to RT samples. The samples were maintained to sintering temperatures from $1000{ }^{\circ} \mathrm{C}$ to $1400{ }^{\circ} \mathrm{C}$ for 10,30 and $120 \mathrm{~min}$. The evolution of the temperatures depended on the injected power and the operator.

The first sample (RT-P4) was heated by increasing the microwave power very slowly (up to $1300 \mathrm{~W}$ ) in order to establish the optimum heating regime by avoiding the thermal runaway phenomenon and microwave plasma arc discharge. The sample codified RT-P5 suffered fast microwave heating and even the microwave power level was lower than RT-P4 $(1200 \mathrm{~W})$; the sintering temperature was reached in $50 \%$ of the heating time. Based on the results obtained for RT-P4 and RT-P5, the level of the microwave power was reduced (down to $1140 \mathrm{~W}$ for RT-P6) but the sintering time was increased to $120 \mathrm{~min}$. The last two samples (RT-P7 and RT-P8) were heated with $1560 \mathrm{~W}$ and $1200 \mathrm{~W}$, respectively, in order to achieve high sintering temperature and low sintering time. Regarding the stability and performance of the process, the power balance for hybrid heating provided good results (Figure 13).

\subsubsection{Resistance Heating of the Samples}

The performance of the microwave heating process was evaluated by heating an RT sample using an experimental resistance oven, which can increase the temperature up to $1150{ }^{\circ} \mathrm{C}$. The resistance was powered by a $15 \mathrm{~kW}$ autotransformer with voltage adjustable between 0 and $230 \mathrm{~V}$ alternative current. The Figure 14 presents the experimental device during the resistance heating process.

The process started with $80 \mathrm{~V}$ provided by autotransformer and the temperature was measured using infrared pyrometer Optris CT Glass G5H. The Figure 14 presents the results of temperature recording during the heating process to $1150^{\circ} \mathrm{C}$. The total sintering time was $10 \mathrm{~min}$, which revealed the properties of the RT-P9. The results were compared with those obtained from the microwave process. 


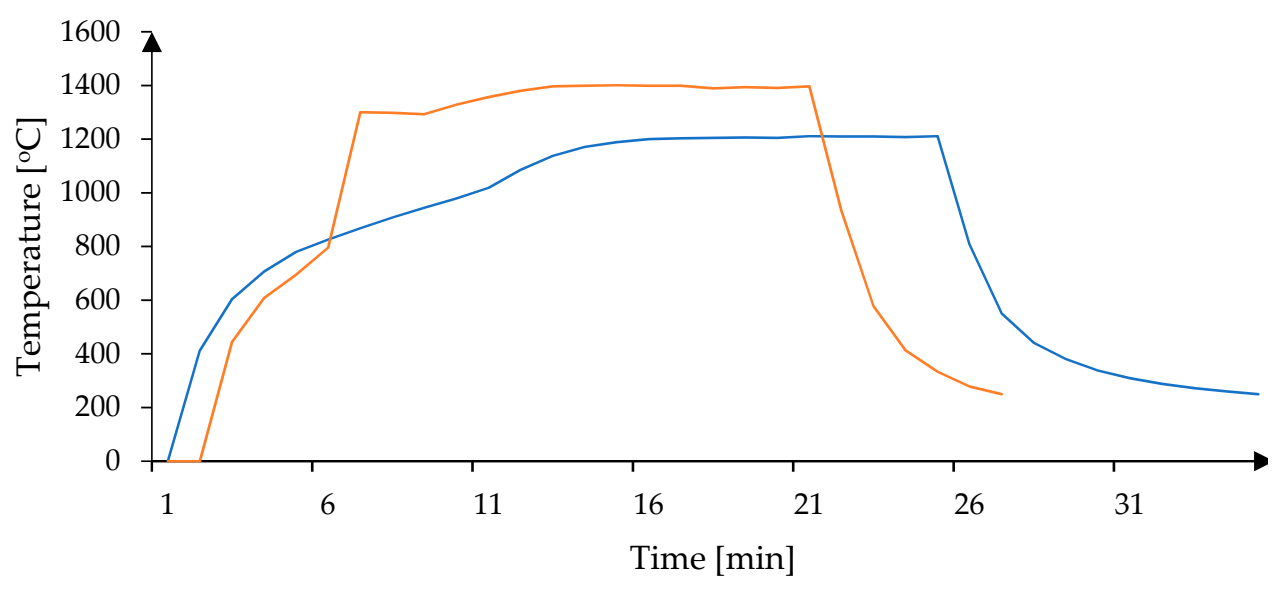

- RT-P7 - RT-P8

(a)

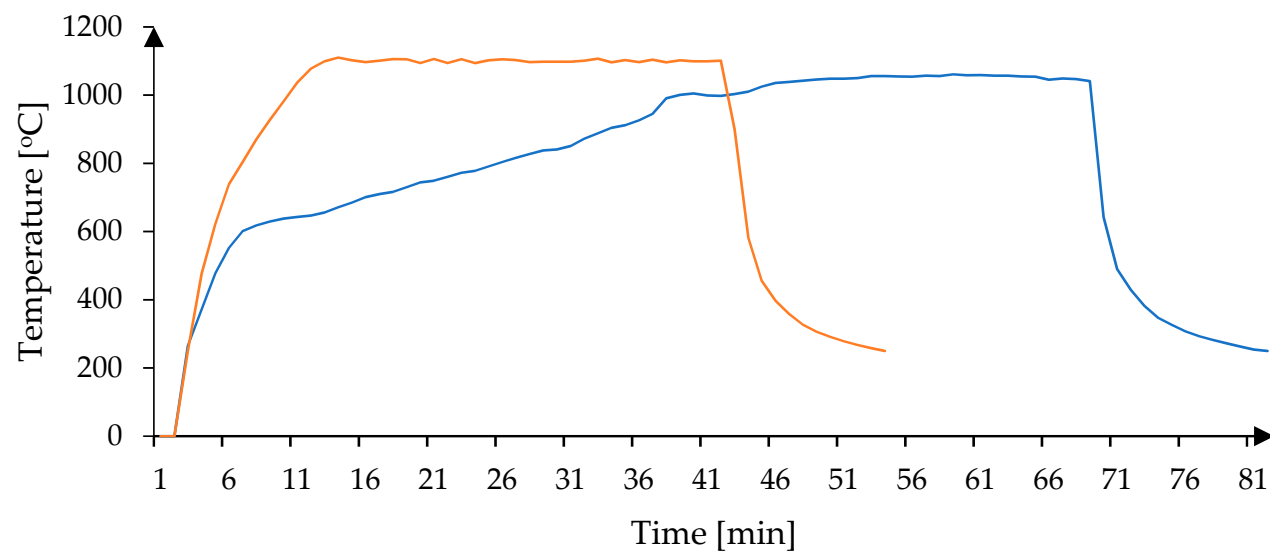

- RT-P4 - RT-P5

(b)

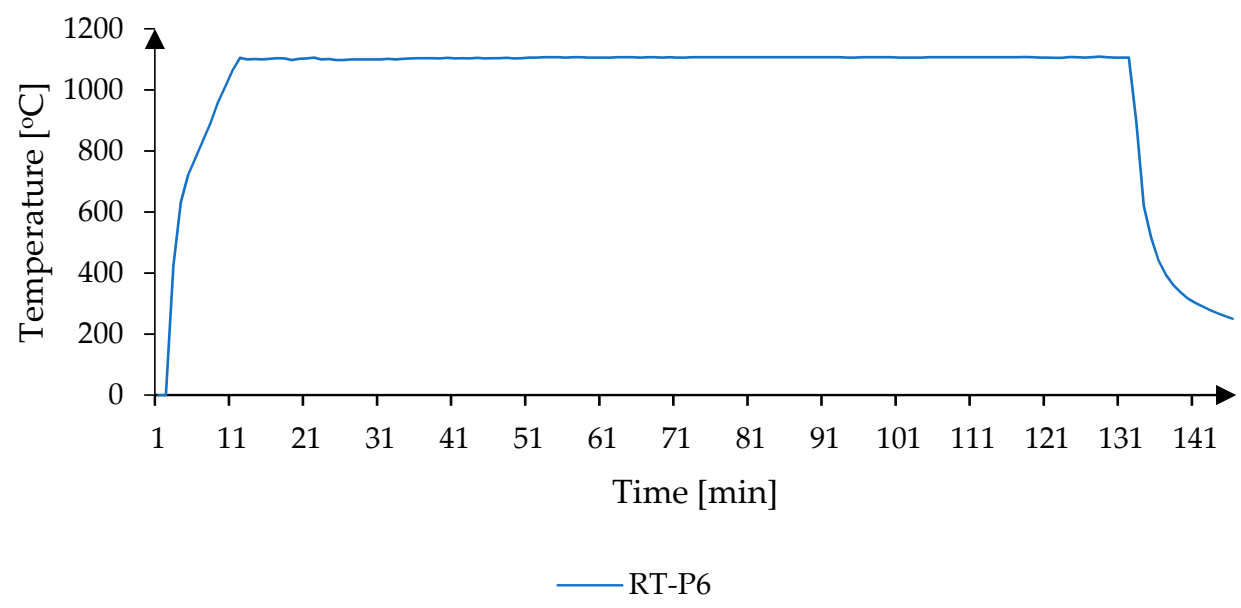

(c)

Figure 12. Temperatures in hybrid microwave heating: (a) process parameters: sintering time for $10 \mathrm{~min}$ at $1200-1400{ }^{\circ} \mathrm{C},(\mathbf{b})$ sintering time for $30 \mathrm{~min}$ at $1000-1100{ }^{\circ} \mathrm{C},(\mathbf{c})$ sintering time for $120 \mathrm{~min}$ at $1100{ }^{\circ} \mathrm{C}$. 


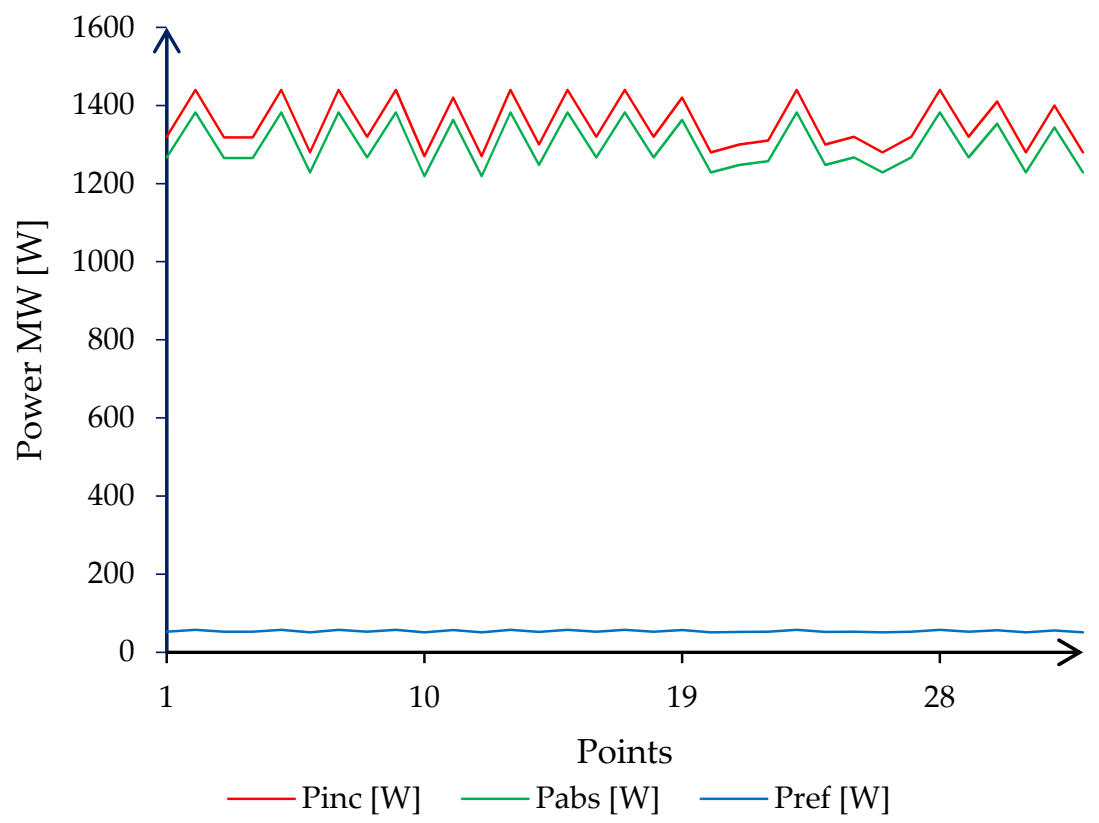

(a)

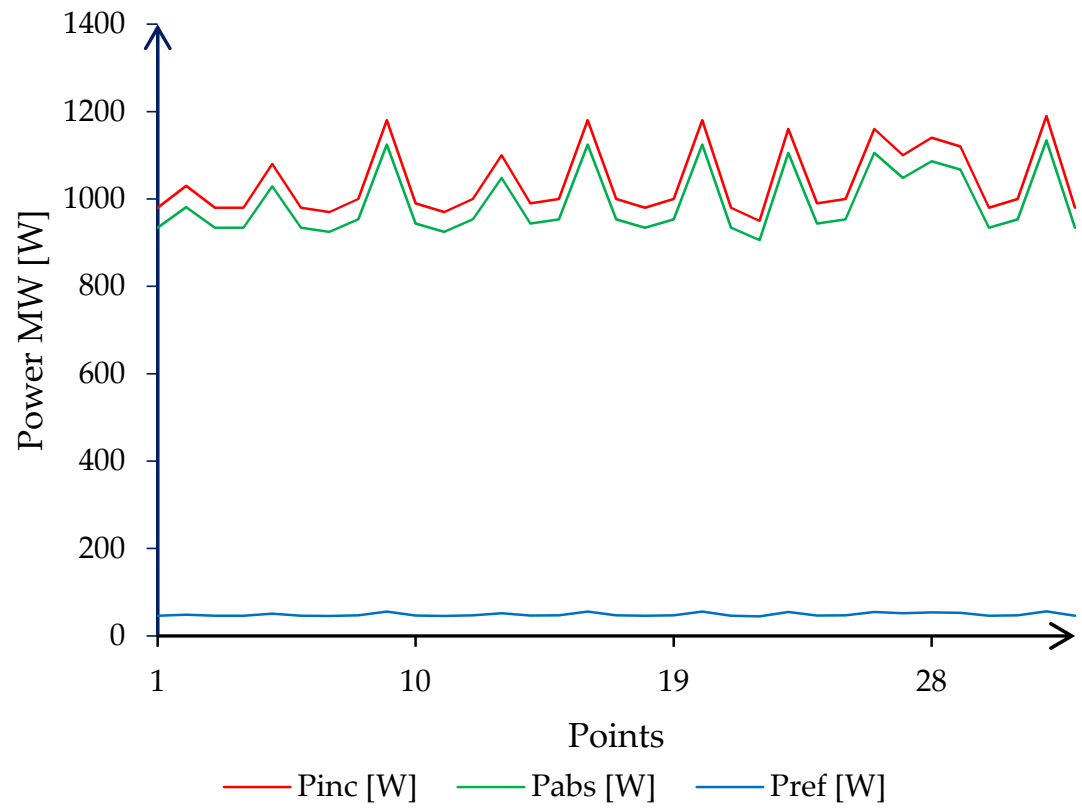

(b)

Figure 13. Cont. 


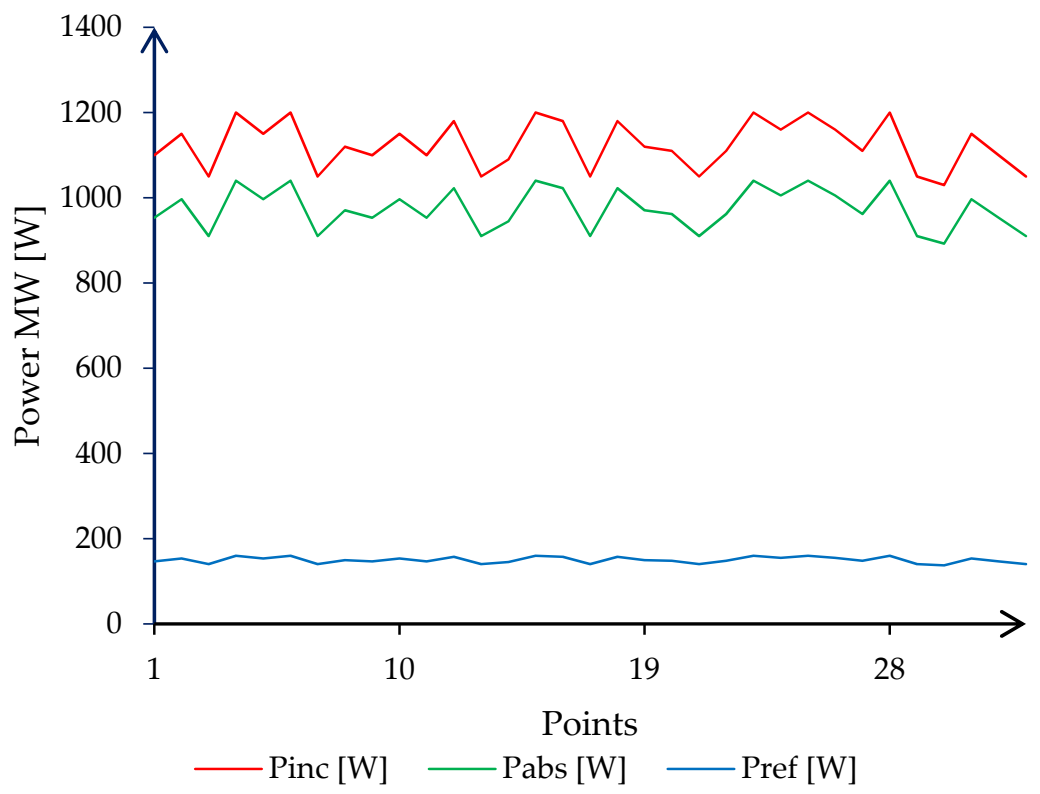

(c)

Figure 13. Evaluation of the performance of hybrid microwave heating: (a) RT-P7 and RT-P8: 96\% for RT-P7 and 81\% for RT-P8, (b) RT-P4 and RT-P5: 95.3\% for RT-P4 and 99.67\% for RT-P5, (c) RTP6, 86.66\%.
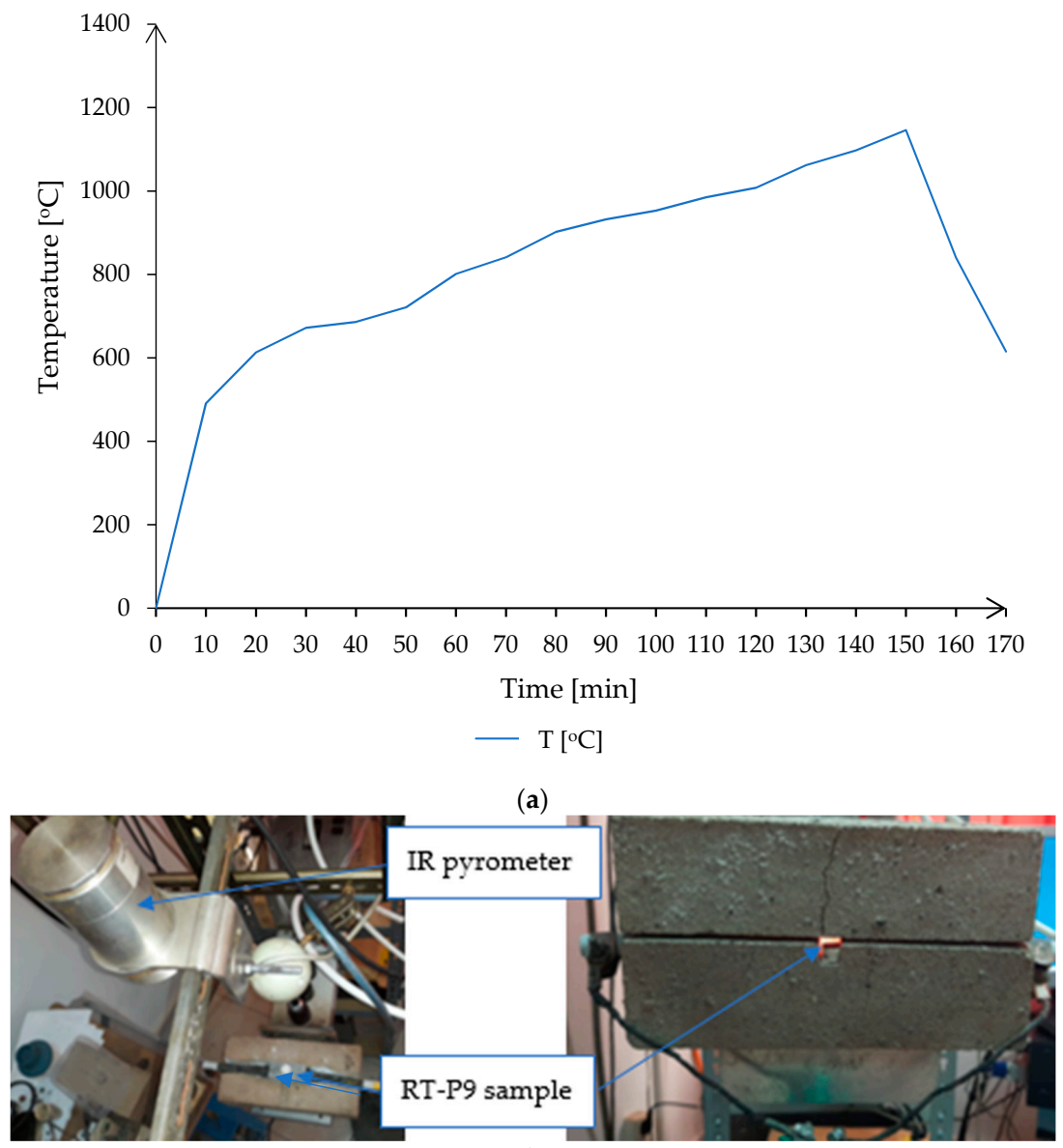

(b)

Figure 14. Resistance heating of RT samples: (a) temperature evolution, (b) experimental resistance oven. 
In order to determine the micro hardness of the samples, a micro hardness tester Namicon was employed. Three measurements were performed starting from the edge of the sample up to the center to determine the micro hardness for each sample. The measurements were performed on two different samples: RT-P8 was sintered at $1300-1400{ }^{\circ} \mathrm{C}$ and maintained at this temperature for $10 \mathrm{~min}$, but the entire process lasted for 169 min while RT-P9 was sintered at $1000-1150{ }^{\circ} \mathrm{C}$ with a dwell time of $10 \mathrm{~min}$.

The microstructures were analyzed using Nikon Eclipse MA 100 compact-sized inverted microscope driven by NIS-Elements imaging software 3.03.

The wear tests were employed using a reciprocating module from the CSM tribometer (Switzerland) with max torque $450 \mathrm{Nmm}$ and max load $46 \mathrm{~N}$. The testing process was driven by InstrumX software. The frequency allowed was up to $1.6 \mathrm{~Hz}$ having a linear speed range $0.3-500 \mathrm{~mm} / \mathrm{s}$, stroke range $60 \mathrm{~mm}$ and an acquisition rate of $10 \mathrm{~Hz}$.

The wear rate and friction coefficient were determined with balls fabricated from DIN $100 \mathrm{Cr}_{6}$ having $6 \mathrm{~mm}$ diameter. The HRc density was higher than $7.6 \mathrm{~g} / \mathrm{cm}^{3}$. The RT products represented the static counter piece. The friction parameters employed were sliding linear velocity $2 \mathrm{~cm} / \mathrm{s}$ using an acquisition rate of $10 \mathrm{~Hz}$ in ambient temperature $22{ }^{\circ} \mathrm{C}$ and humidity $30 \%$. The samples were tested with $4 \mathrm{~N}$ load and $3 \mathrm{~mm}$ amplitude. The maximum speed was $2 \mathrm{~cm} / \mathrm{s}$, motor speed $127.32 \mathrm{rpm}$ and distance $5 \mathrm{~m}$.

The surface roughness and the wear rate were recorded using a Taylor Hobson Precision, TALYSURF profilometer (United Kingdom)

\section{Results}

The micro hardness tests were performed with a Namicon micro hardness tester CV-400DM produced by CV Instruments Europe BV (the Netherlands) and the results were as follows. A preliminary measurement HV25 was performed in order to calibrate the equipment and then HV1000 measurements were performed. For both samples, the results can be consulted in the Table 4 and Figure 15.

Table 4. Micro hardness of the samples sintered by hybrid microwave and resistance heating.

\begin{tabular}{ccc}
\hline Point & HV 1000 (RT-P8) & HV 1000 (RT-P9) \\
\hline 1 & 450 & 740 \\
2 & 517 & 763 \\
3 & 665 & 780 \\
\hline
\end{tabular}

The micro hardness of the tested samples RT-P8 and RT-P9 reveals the influence of the sintering process employed (hybrid microwave heating vs. resistance heating). The results of the simulation showed that the temperature achieved on the bottom of the RT sample was $1392{ }^{\circ} \mathrm{C}$ and $1396{ }^{\circ} \mathrm{C}$ on the top of the RT sample. During the experimental procedure, the samples were maintained at sintering temperatures from $1000{ }^{\circ} \mathrm{C}$ to $1400{ }^{\circ} \mathrm{C}$ for 10,30 and $120 \mathrm{~min}$. In terms of temperature and the sintering time, the micro hardness values were comparable for RT-P9 and RT-P8. The sample RT-P9 was heated using classical heating in an oven with electrical resistance up to $1100-1150{ }^{\circ} \mathrm{C}$ and maintained for $10 \mathrm{~min}$ and the entire process lasted for $169 \mathrm{~min}$. In the case of RT-P8, the temperature employed was $1300-1400{ }^{\circ} \mathrm{C}$ and the dwell time was $10 \mathrm{~min}$, but hybrid microwave heating was employed. Another aspect that has to be outlined is the slight difference in terms of micro hardness measurements from the center of the sample to the edge of the sample. For RT-P8 the micro hardness recorded near the center of the sample was slightly diminished compared to the micro hardness recorded near the edge of the sample. A possible explanation of this phenomenon is the hybrid heating combining microwave heating and conduction heating from the crucible used. Therefore, while in the center of the sample the predominant heating mechanism is microwave related, at the edge of the sample, we encounter a dual mechanism for the heating field, i.e., microwave and thermal conduction. This was also confirmed by the modelling of the thermal field presented above. The micro hardness 
values for RT-P9 are quite close due to the classical sintering process, which has not been influenced by the microwave field.

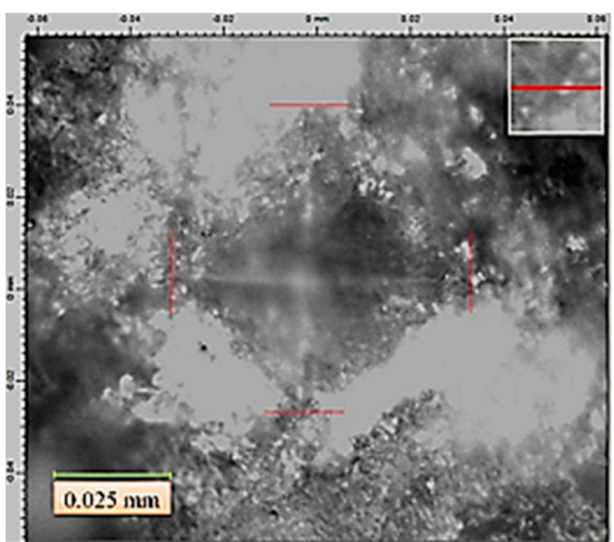

(a)

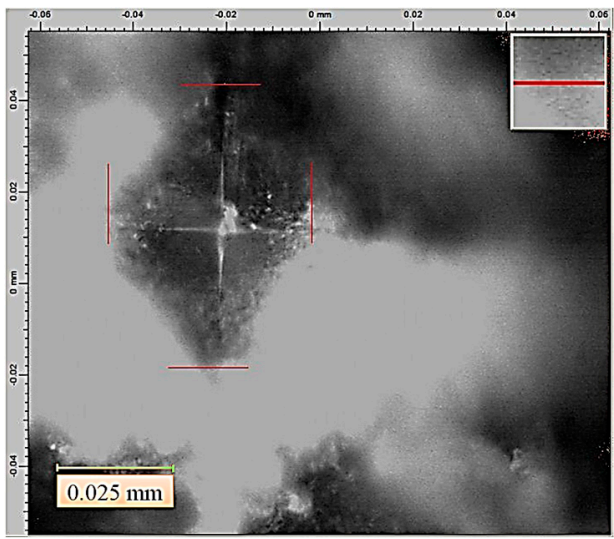

(c)

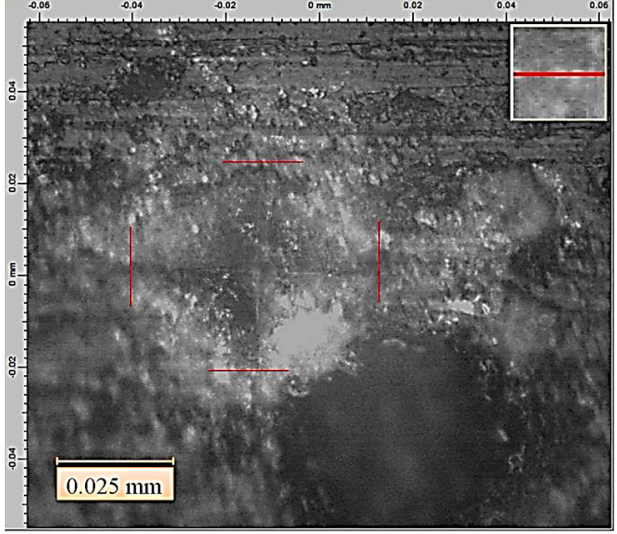

(e)

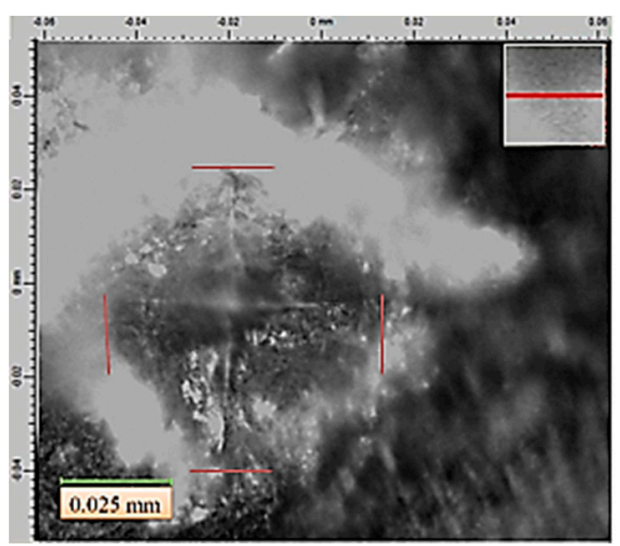

(b)

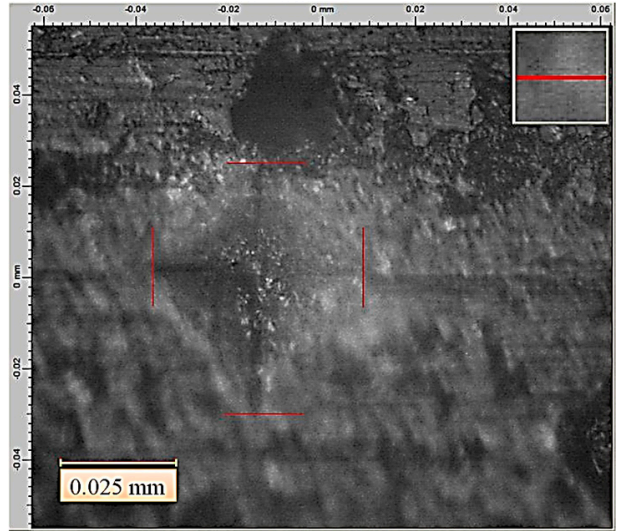

(d)

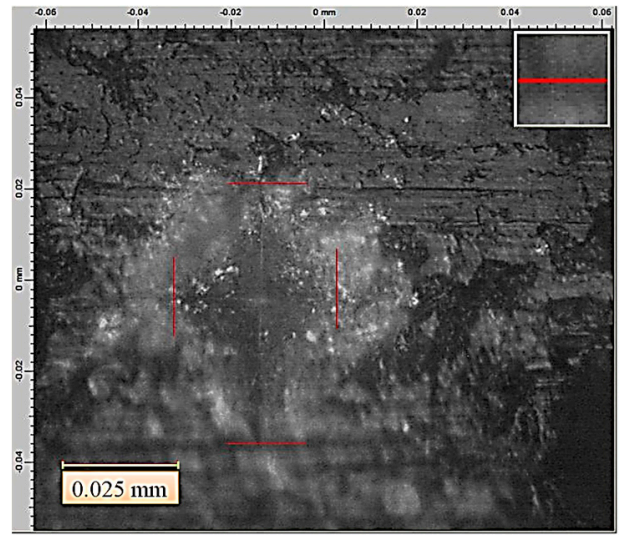

(f)

Figure 15. Tracks of the indenter for the three values of the micro hardness: (a) $450 \mathrm{HV}$, (b) $517 \mathrm{HV}$, (c) $665 \mathrm{HV}$, (d) $740 \mathrm{HV}$, (e) $780 \mathrm{HV}$, (f) $763 \mathrm{HV}$.

As far as the wear is concerned, the wear rates recorded for both RT-P8 and RT-P9 are comparable, which is confirmed by the micro hardness measurements as well. Figure 16 presents the value for the wear test for RT-P8 and Figure 17 shows the values obtained for RT-P9. 


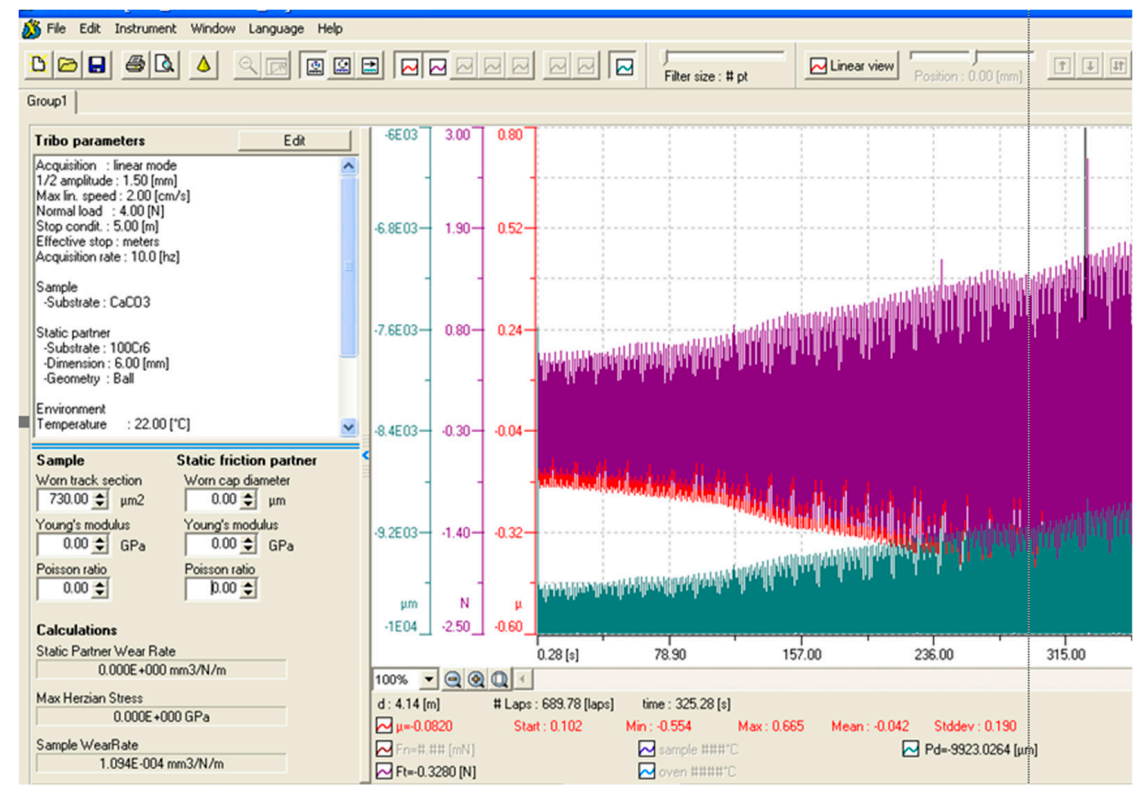

(a)

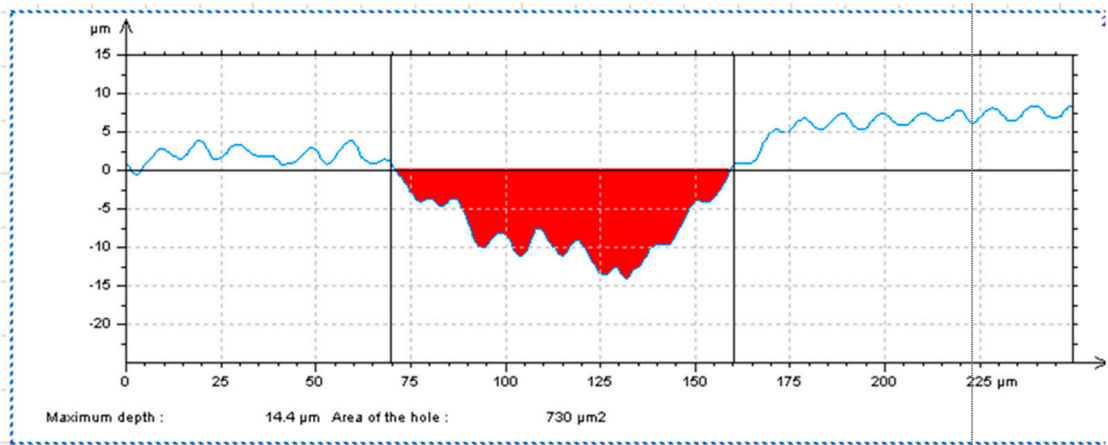

(b)

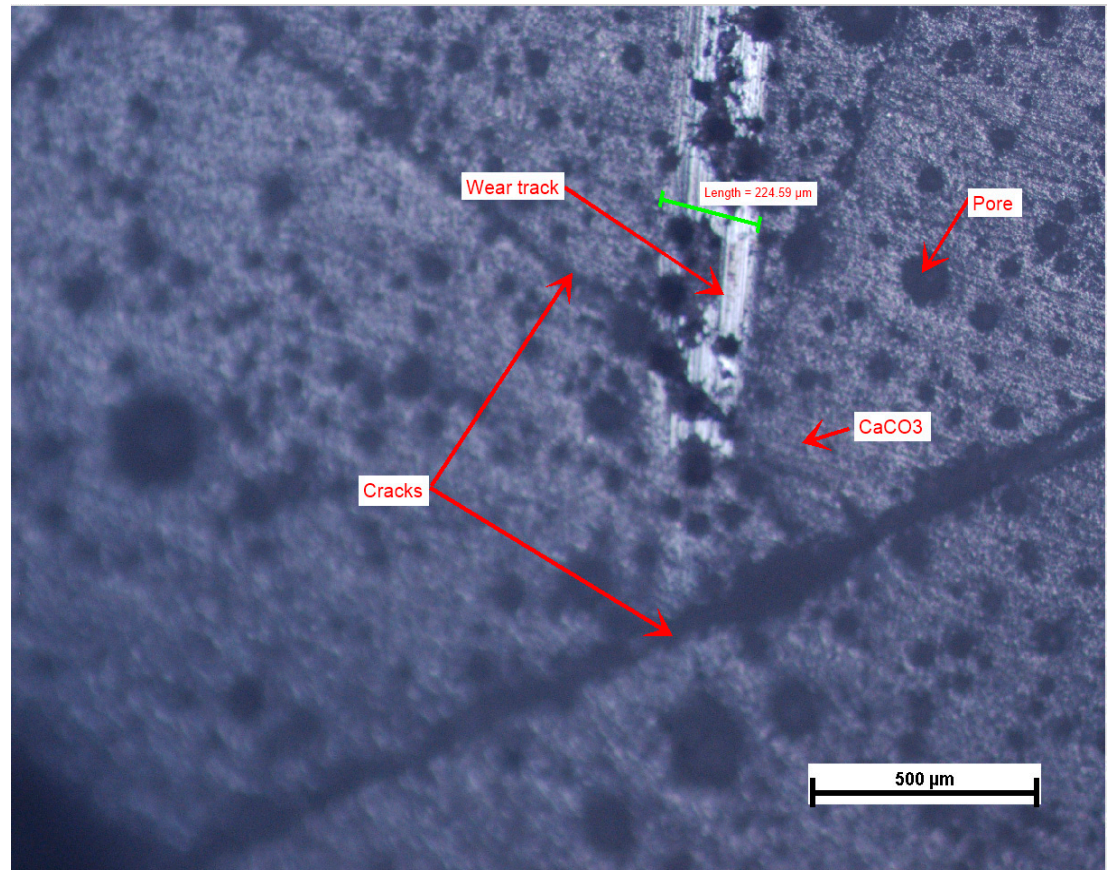

(c)

Figure 16. Values obtained for RT-P8 at wear test: (a) friction coefficient and friction force, (b) wear rate, (c) wear track. 


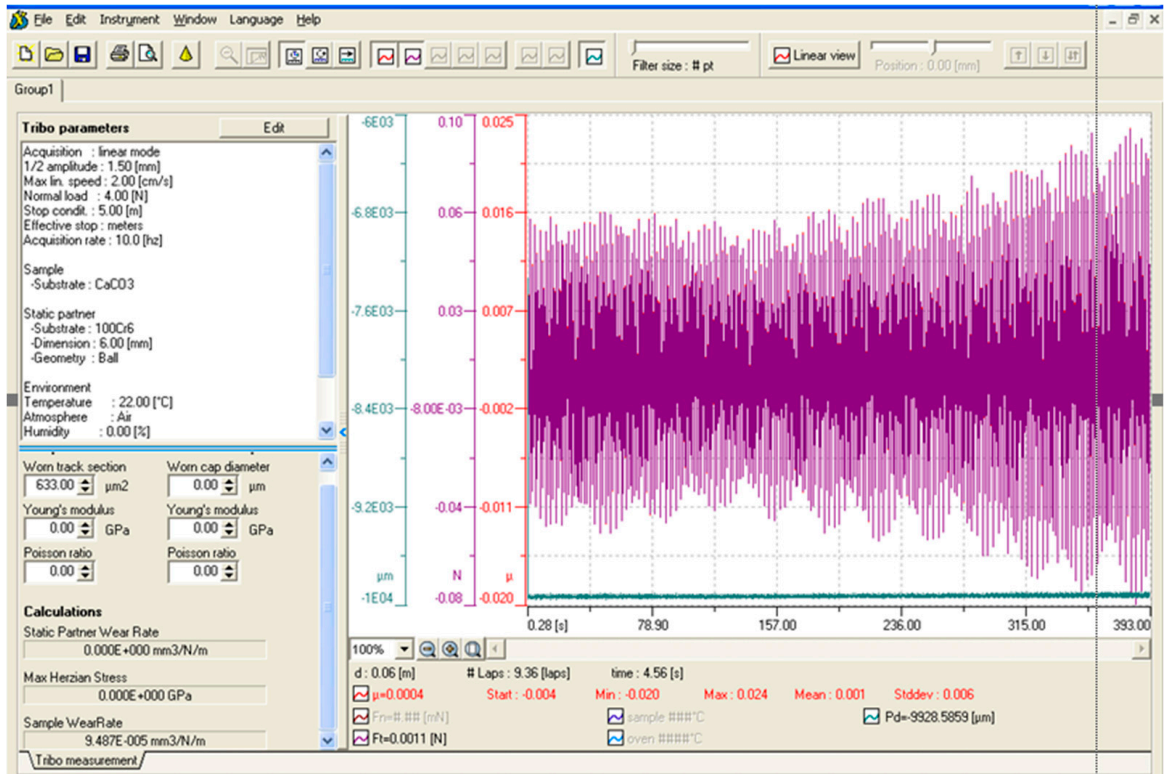

(a)

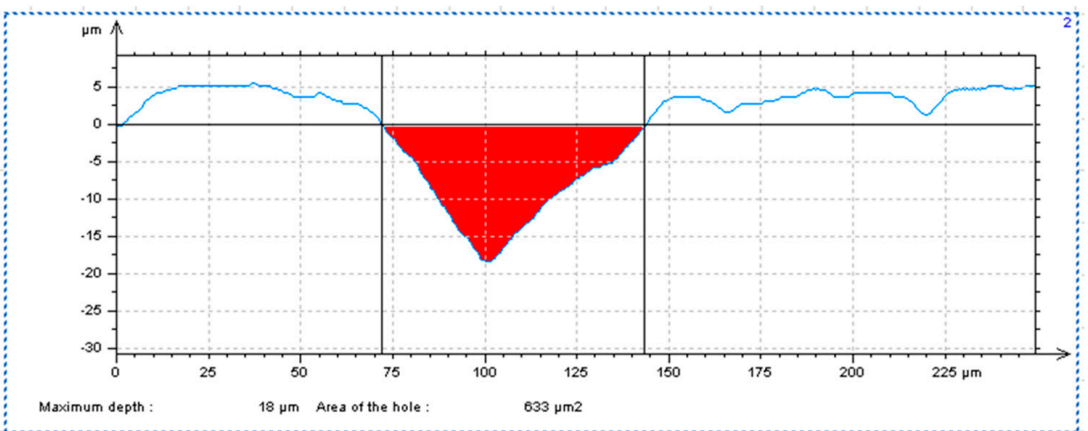

(b)

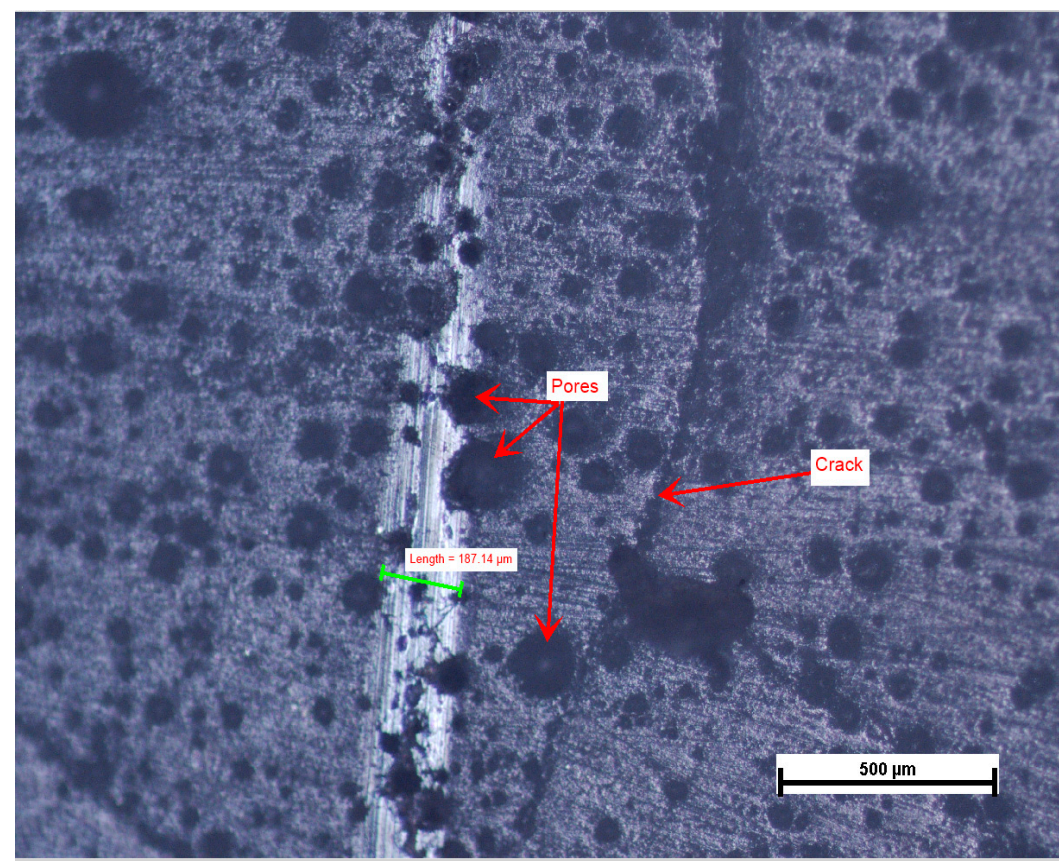

(c)

Figure 17. Values obtained for RT-P9 at wear test: (a) friction coefficient and friction force, (b) wear rate, (c) wear track. 
According to Figures $16 \mathrm{a}$ and 17a, the reduced value of the friction coefficient for both samples can be observed, which is in accordance with the fact that in many cases $\mathrm{CaCO}_{3}$ is used to reduce the friction [86]. The wear rates presented in Figures $16 \mathrm{~b}$ and $17 \mathrm{~b}$ show close wear rates for both samples irrespective of the sintering process applied. This validates the results obtained for micro hardness. Concerning the pattern of the track wear in both Figures $16 \mathrm{c}$ and $17 \mathrm{c}$, cracks and pores are visible. The cracks can be a consequence of the sintering process and the pores could be the result of the compacting conditions and microstructure of the $\mathrm{CaCO}_{3}$ samples.

\section{Discussion}

Microwave heating represents an advanced technology for processing solid waste materials. In this paper, the authors aimed to develop a technology for sintering the powders from RT seashells. The performance of the heating for microwave processing (direct microwave heating and hybrid microwave heating) as well as resistance heating is the subject of the discussion in terms of process performance and sustainable development. In terms of microwave heating, both technologies can be applied if the heating mechanism conditions are well established. Therefore, a model of injected power for achieving the sintering temperature can be elaborated.

In Figure 18, the interdependence between microwave power and temperature developed by RT-P2 and RT-P8 samples is presented. These samples were selected based on presented stability during heating as well as the mechanical properties evaluated after the sintering process. The mathematical model for direct microwave heating is presented in the equation below [92].

$$
P_{M W \_d i r e c t \_h e a t i n g}=19.48 \ln t+594.16
$$

where: $P_{M W \_d i r e c t \_h e a t i n g}$ represents the total injected power from microwave generator and $\mathrm{t}$ represents the total heating time. Similarly, for hybrid microwave heating, a polynomial function can be expressed as following [93].

$$
P_{M W \_h y b r i d \_h e a t i n g}=0,0153 \cdot t^{4}-0.9566 \cdot t^{3}+18.334 \cdot t^{2}-80.088 \cdot t+683.19
$$

where: $P_{M W \_ \text {hybrid_heating }}$ represents the total injected power from the microwave generator and $t$ represents the total heating time. On the other hand, the processing of solid waste material should be sustainable from a carbon footprint point of view. The total electrical energy used in microwave heating can be calculated based on equipment technical specifications provided by the manufacturer:

$$
P_{M W \_p r o c e s s}=P_{M W \_s o u r c e}+\sum P_{\text {auxiliary_devices }}
$$

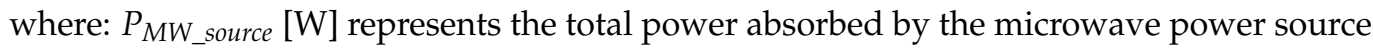
in order to power the magnetron and $P_{\text {auxilliary_devices }}[\mathrm{W}]$ represents the total power absorbed from the electrical grid for infrared pyrometer Optris CT Glass G5H, matching load autotuner Tristan, process computers and external displays for process monitoring. Taking into account that infrared pyrometer $(24 \mathrm{~V} \mathrm{DC}, 0.5 \mathrm{~A})$ and matching load autotuner $(24 \mathrm{~V}$ DC and $2.5 \mathrm{~A}$ ) are powered with direct current from a power source, the evaluation of these two devices will be conducted by considering the measurement of the real consumption. The measurements were performed with Metrix MTX 3250 DMM (Metrix, MTX 3520, 2007, France) and the value recorded during the heating process was $120 \mathrm{~W}$. The computer process absorbed $400 \mathrm{~W}$ for the processing unit and an additional $500 \mathrm{~W}$ for the external displays. The real consumption of microwave installation was measured using Chauvin Arnoux CA 8220 Power Quality Analyser (Chauvin Arnoux, CA8220, 2012, France). The measurement was performed continuously and the maximum power absorbed during 
the heating process was $3500 \mathrm{~W}$. The active energy absorbed from the electrical grid was calculated using the following equation:

$$
E_{M W \_p r o c e s s}=P_{M W \_p r o c e s s} \cdot t_{M W \_ \text {heating }}
$$

where: $E_{M W \_p r o c e s s}$ represents the total active energy consumed for microwave heating of the RT-P8 sample, which presented the best mechanical properties in terms of hardness and wear testing; $t_{M W \_ \text {heating }}$ represents the time of microwave heating for RT-P8 sample. Based on calculation and measurements, total active electrical energy consumed by the microwave heating process was evaluated at $753.33 \mathrm{Wh}$.

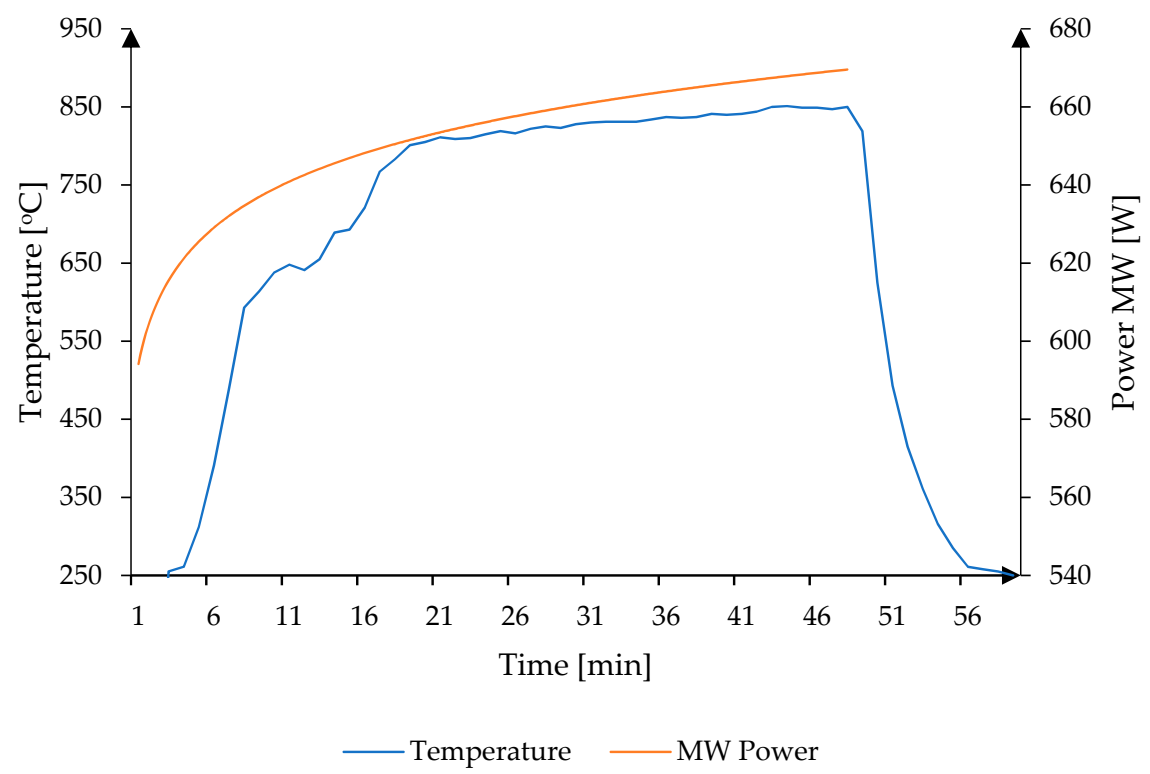

(a)

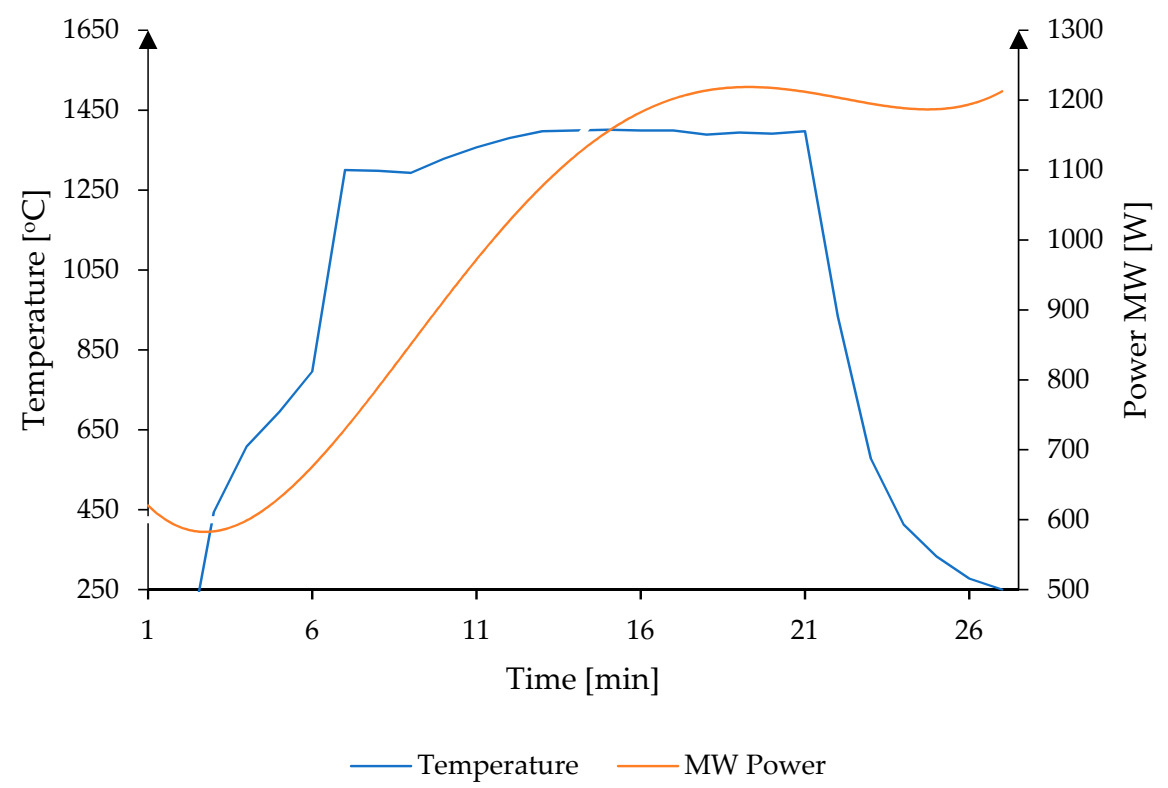

(b)

Figure 18. Microwave power model for fast sintering of RT samples: (a) power curve vs. temperature vs. time for direct microwave heating for RT-P2 sample, (b) power curve vs. temperature vs. time for hybrid microwave heating for RT-P8 sample. 
Regarding the energy consumed by the resistance oven, the total energy was measured using Chauvin Arnoux CA 8220 Power Quality Analyser. The measurements presented a total of $4920 \mathrm{~W}$ for $2 \mathrm{~h}$ and $49 \mathrm{~min}$. The total active energy absorbed from the electrical grid was calculated as $13.825 \mathrm{Wh}$. The microwave heating process is proven to be 20 times better, in terms of energy efficiency, than resistance heating. The difference between these two thermal sources can be found in the Table 5 below.

Table 5. Energy consumption in hybrid microwave heating and resistance heating.

\begin{tabular}{cccc}
\hline Process & Power $[\mathbf{W}]$ & Time $[\mathbf{h}]$ & Energy $[\mathbf{W h}]$ \\
\hline Hybrid Microwave & 3500 & 0.21 & 753.33 \\
Resistance & 4920 & 2.8 & 13,825 \\
\hline
\end{tabular}

Concerning the mechanical properties of the analyzed samples, the RT-P8 and RT-P9 closed values were obtained in terms of both micro hardness and wear rate. However, from the energy consumption point of view, it is obvious that the sintering process with hybrid microwave heating is more efficient due to the reduced time required compared to the classical sintering process.

\section{Conclusions}

Microwave heating represents an advanced technology for processing solid waste, in this case RT, both from domestic activities and natural waste. The technology researched had the objective to obtain viable products with good mechanical properties and biocompatibility for different medical applications. The results confirmed that microwave technology is 20 times better, in terms of energy efficiency, than conventional heating in a resistance oven. However, the technology depends on absorbance properties of the materials heated in the microwave field. RT samples presented good absorbance properties, but the temperatures reached in direct microwave heating did not exceed $850{ }^{\circ} \mathrm{C}$. Beyond this temperature, the microwave plasma arc discharge occurred and the samples were not sintered. In order to achieve the sintering temperature, hybrid microwave heating was employed. This procedure proved to be sustainable from an energy efficiency and stability of heating process point of view. The process led to temperatures up to $1400{ }^{\circ} \mathrm{C}$ and $10 \mathrm{~min}$ dwell time. The mechanical tests, in terms of micro hardness and wear rate, presented similar values as the use of conventional heating.

The study of hybrid microwave heating offers good perspectives in utilization of microwave technology for processing solid waste materials. In addition, this study provides information for further sintering processes of metallic materials or joining processes such as glass and polymer welding.

Author Contributions: Conceptualization: S.V.S. and D.T., Methodology: S.V.S., G.C.B. and I.D.S., Investigation: S.V.S., I.S., N.C. and A.B.O., Resources: I.D., Writing original: S.V.S., I.D.S. and G.C.B., Writing, review and editing: S.V.S. and D.T. All authors have read and agreed to the published version of the manuscript.

Funding: This research was funded by UEFISCDI, grant number 499/2020. The APC was funded by University of Craiova.

Institutional Review Board Statement: The study was conducted according to the guidelines of the Declaration of Helsinki, and approved by the Institutional Review Board of University of Craiova.

Informed Consent Statement: Not applicable.

Data Availability Statement: No data were reported.

Acknowledgments: This paper was supported by the Project no.499/2020, code PN-III-P2-2.1-PED2019, entitled "New product fabricated by extrusion-based 3D printing from marine bio-waste (3D BIOPRO)", financed by UEFISCDI.

Conflicts of Interest: The authors declare no conflict of interest. 


\section{References}

1. Ehrlich, H. Marine Biological Materials of Invertebrate Origin, 1st ed.; Springer Nature Switzerland AG: Cham, Switzerland, 2019; pp. 1-209.

2. Mora, C.; Tittensor, D.P.; Adl, S.; Simpson, A.G.B.; Worm, B. How many species are there on earth and in the ocean? PLoS Biol. 2011, 9, e1001127. [CrossRef]

3. Khrunyk, Y.; Lach, S.; Petrenko, I.; Ehrlich, H. Progress in modern marine biomaterials research. Mar. Drugs 2020, 589-635. [CrossRef] [PubMed]

4. Powers, D.A. New frontiers in marine biotechnology: Opportunities for the 21st century. In Marine Biotechnology in the Asian Pacific Region; SAREC: Bangkok, Thailand, 1995.

5. Leary, D.; Vierros, M.; Hamon, G.; Arico, S.; Monagle, C. Marine genetic resources: A review of scientific and commercial interest. Mar. Policy 2009, 33, 183-194. [CrossRef]

6. Binnewerg, B.; Schubert, M.; Voronkina, A.; Muzychka, L.; Wysokowski, M.; Petrenko, I.; Djurović, M.; Kovalchuk, V.; Tsurkan, M.; Martinovic, R.; et al. Marine biomaterials: Biomimetic and pharmacological potential of cultivated Aplysina aerophoba marine demosponge. Mater. Sci. Eng. C Mater. Biol. Appl. 2020, 109, 110566-110577. [CrossRef] [PubMed]

7. Wan, M.-c.; Qin, W.; Lei, C.; Li, Q.-h.; Meng, M.; Fang, M.; Song, W.; Chen, J.-h.; Tay, F.; Niu, L. Biomaterials from the sea: Future building blocks for biomedical applications. Bioact. Mater. 2021, 6, 4255-4285. [CrossRef] [PubMed]

8. Lalzawmliana, V.; Anand, A.; Prasenjit, M.; Shubhamitra, C.; Kundu, B.; Samit Nandi, K.; Narsinh, L. Thakur. Marine organisms as a source of natural matrix for bone tissue engineering. Ceram. Int. 2019, 45, 1469-1481. [CrossRef]

9. Ghaly, A.; Ramakrishnan, V.; Brooks, M.; Budge, S.; Dave, D. Fish processing wastes as a potential source of proteins, amino acids and oils: A critical review. J. Microb. Biochem. Technol. 2013, 5, 107-129.

10. Lee, M.; Tsai, W.; Chen, S. Reusing shell waste as a soil conditioner alternative? A comparative study of eggshell and oyster shell using a life cycle assessment approach. J. Clean. Prod. 2020, 265, 121845. [CrossRef]

11. Alvarenga, R.A.F.d.; Galindro, B.M.; Helpa, C.d.F.; Soares, S.R. The recycling of oyster shells: An environmental analysis using Life Cycle Assessment. J. Environ. Manag. 2012, 106, 102-109. [CrossRef] [PubMed]

12. Iribarren, D.; Moreira, M.T.; Feijoo, G. Implementing by-product management into the life cycle assessment of the mussel sector. Resour. Conserv. Recycl. 2010, 54, 1219-1230. [CrossRef]

13. Sowmya, R.; Ravikumar, T.M.; Vivek, R.; Rathinaraj, K.; Sachindra, N.M. Optimization of enzymatic hydrolysis of shrimp waste for recovery of antioxidant activity rich protein isolate. J. Food Sci. Technol. 2014, 51, 3199-3207. [CrossRef] [PubMed]

14. De Holanda, H.D.; Netto, F.M. Recovery of components from shrimp (Xiphopenaeus kroyeri) processing waste by enzymatic hydrolysis. J. Food Sci. 2006, 71, C298-C303. [CrossRef]

15. Zhang, K.; Zhang, B.; Chen, B.; Jing, L.; Zhu, Z.; Kazemi, K. Modeling and optimization of Newfoundland shrimp waste hydrolysis for microbial growth using response surface methodology and artificial neural networks. Mar. Pollut. Bull. 2016, 109, 245-252. [CrossRef] [PubMed]

16. El-Fattah, M.A.; El Saeed, A.M.; Azzam, A.M.; Abdul-Raheim, A.-R.M.; Hefni, H.H.H. Improvement of corrosion resistance, antimicrobial activity, mechanical and chemical properties of epoxy coating by loading chitosan as a natural renewable resource. Prog. Org. Coat. 2016, 101, 288-296. [CrossRef]

17. Ge, H.; Zhao, B.; Lai, Y.; Hu, X.; Zhang, D.; Hu, K. From crabshell to chitosan-hydroxyapatite composite material via a biomorphic mineralization synthesis method. J. Mater. Sci. Mater. Med. 2010, 21, 1781-1787. [CrossRef] [PubMed]

18. Vijayaraghavan, K.; Winnie, H.Y.N.; Balasubramanian, R. Biosorption characteristics of crab shell particles for the removal of manganese (II) and zinc (II) from aqueous solutions. Desalination 2011, 266, 195-200. [CrossRef]

19. Monteiro, R.J.R.; Lopes, C.B.; Rocha, L.S.; Coelho, J.P.; Duarte, A.C.; Pereira, E. Sustainable approach for recycling seafood wastes for the removal of priority hazardous substances (Hg and Cd) from water. J. Environ. Chem. Eng. 2016, 4, 1199-1208. [CrossRef]

20. Jeon, C. Adsorption behavior of silver ions from industrial wastewater onto im- mobilized crab shell beads. J. Ind. Eng. Chem. 2015, 32, 195-200. [CrossRef]

21. Joseph Sherin, M.; Krishnamoorthy, S.; Paranthaman, R.; Moses, J.A.; Anandharamakrishnan, C. A review on source-specific chemistry, functionality, and applications of chitin and chitosan. Carbohydr. Polym. Technol. Appl. 2021, 2, 100036.

22. Dima, J.B.; Sequeiros, C.; Zaritzky, N. Chitosan from marine crustaceans: Production, characterization and applications. In Biological Activities and Application of Marine Polysaccharides; InTech: Rijeka, Croatia, 2017.

23. Oyatogun, G.; Esan, T.; Akpan, E.; Adeosun, S.; Popoola, A.; Imasogie, B.; Soboyejo, W.; Afonja, A.; Ibitoye, S.; Abere, V. Handbook of Chitin and Chitosan; Elsevier: Amsterdam, The Netherlands, 2020.

24. Cheung, R.C.F.; Ng, T.B.; Wong, J.H.; Chan, W.Y. Chitosan: An update on potential biomedical and pharmaceutical applications. Mar. Drugs 2015, 13, 5156-5186. [CrossRef]

25. Dongre, R.S. Introductory chapter: Multitask portfolio of chitin/chitosan: Biomatrix to quantum dot. Chitin Chitosan Myriad Funct. Sci. Technol. 2018. [CrossRef]

26. Antoniraj, M.G.; Leena, M.M.; Moses, J.A.; Anandharamakrishnan, C. Cross-linked chitosan microparticles preparation by modified three fluid nozzle spray drying approach. Int. J. Biol. Macromol. 2020, 147, 1268-1277. [CrossRef] [PubMed]

27. Bharathi, S.K.V.; Leena, M.M.; Moses, J.A.; Anandharamakrishnan, C. Nanofi- bre-based bilayer biopolymer films: Enhancement of antioxidant activity and potential for food packaging application. Int. J. Food Sci. Technol. 2020, 55, 1477-1484. [CrossRef] 
28. Bumgardner, J.D.; Murali, V.P.; Su, H.; Jenkins, O.D.; Velasquez-Pulgarin, D.; Jennings, J.A. Characterization of chitosan matters. In Chitosan Based Biomaterials; Woodhead Publishing, 2017.

29. Barbosa, A.I.; Coutinho, A.J.; Costa Lima, S.A.; Reis, S. Marine polysaccharides in pharmaceutical applications: Fucoidan and chitosan as key players in the drug delivery match field. Mar. Drugs 2019, 17, 654. [CrossRef] [PubMed]

30. Abdelmalek, B.E.; Sila, A.; Haddar, A.; Bougatef, A.; Ayadi, M.A. $\beta$-Chitin and chitosan from squid gladius: Biological activities of chitosan and its application as clarifying agent for apple juice. Int. J. Biol. Macromol. 2017, 104, 953-962. [CrossRef] [PubMed]

31. Huang, L.; Bi, S.; Pang, J.; Sun, M.; Feng, C.; Chen, X. Preparation and characterization of chitosan from crab shell (Portunus trituberculatus) by $\mathrm{NaOH}$ /urea solution freeze-thaw pretreatment procedure. Int. J. Biol. Macromol. 2020, 147, 931-936. [CrossRef]

32. Hill, E.A.; Hunt, C.O.; Lucarini, G.; Mutri, G.; Farr, L.; Barker, G. Land gastropod piercing during the Late Pleistocene and early Holocene in the Haua Fteah, Libya. J. Archaeol. Sci. Rep. 2015, 4, 320-325. [CrossRef]

33. Anonymous. World: Snails (Except Seas Snails)—Market Report. Analysis and Forecast to 2025; IndexBox, Inc., 2018.

34. Pissia, M.A.; Matsakidou, A.; Kiosseoglou, V. Raw materials from snails for food preparation. Future Foods 2021, 3 , 100034. [CrossRef]

35. Massari, S.; Pastore, S. Helciculture and snail caviar: New trends in the food sector. In Commodity Science in Reasearch and Practice Future Trends and Challenges in the Food Sector; Miśniakiewicz, M., Popek, S., Eds.; Polish Society of Commodity Science Cracow: Poland, 2014; pp. 79-90.

36. Ruys, A.J.; Wei, M.; Sorrell, C.C.; Dickson, M.R.; Brandwood, A.; Milthorpe, B.K. Sintering effects on the strength of hydroxyapatite. Biomaterials 1995, 16, 409-415. [CrossRef]

37. Demirel, N.; Ulman, A.; Ylldız, T.; Erto“ r-Akyazi, P. A moving target: Achieving good environmental status and social justice in the case of an alien species, Rapa whelk in the Black Sea. Mar. Policy 2021, 132, 104687. [CrossRef]

38. Mann, R.; Occhipinti, A.; Harding, J.M. ICES, Alien species alert: Rapana venosa (veined whelk) In (Eds). ICES Coop. Res. Rep. N. 2004, 264, 1-14.

39. Chukhchin, V.D. Ecology of the Gastropod Molluscs of the Black Sea; Academy of Sciences of the USSR, Kiev Naukova Dumka: Kyiv, Ukraine, 1984; pp. 1-175.

40. Saglam, H.; Duzgunes, E. Rapa Whelk (Rapana venosa Valenciennes, 1846) Fisheries in the Black Sea. In Turkish fisheries in the Black Sea; Duzgunes, E., Ozturk, B., Zengin, M., Eds.; Turk. Mar. Res. Found.: Istanbul, Turkey, 2014; Volume 40, pp. 305-339.

41. Harding, J.M.; Mann, R. Observations on the biology of the veined Rapa whelk, Rapana venosa (Valenciennes, 1846) in the Chesapeake Bay. J. Shellfish Res. 1999, 18, 9-17.

42. Spotorno-Oliveira, P.; Pereira Lopes, R.; Larroque, A.; Monteiro, D.; Dentzien-Dias, P.; de Souza Tamega, F.T. First detection of the non-indigenous gastropod Rapana venosa in the southernmost coast of Brazil. Cont. Shelf Res. 2020, 194, 104047. [CrossRef]

43. Düzgüneş, E.; Kasapoğlu, N.; Şahin, A.; Sağlam, H. Responses to the invasive species in the Black Sea. In Proceedings of the International Conference on "Biodiversity of the Aquatic Environment" Towards a Diverse and Sustainable World, Lattakia, Suriye, 13-15 December 2010; pp. 25-32.

44. FishStat, Fisheries and Aquaculture Software-Universal Software for Fishery Statistical Time Series; 2020.

45. STECF, Scientific, Technical and Economic Committee for Fisheries Assessment of Black Sea Stocks (STECF-17-16); Cardinale, M., Ed.; 2017.

46. Govorin, I.A. The Predatory Marine Gastropod Rapana venosa (Valenciennes, 1846) in Northwestern Black Sea: Morphometric Variations, Imposex Appearance and Biphallia Phenomenon. In Molluscs; Intechopen, 2019.

47. EU Non-Native Species Risk Analysis-Risk Assessment Rapana Venosa v4. Available online: https://circabc.europa.eu (accessed on 12 October 2021).

48. Sereanu, V.; Mihai, M.; Meghea, I. Shell Morphology of Rapana thomasiana Sampled from the Romanian Black Sea Coast. In Proceedings of the SGEM 2014 Conference, Albena, Bulgaria, 17-26 June 2014; 2014; Volume 2, p. 531.

49. Savu, I.D.; Tarniță, D.; Savu, S.V.; Benga, G.; Cursaru, L.-M.; Dragut, D.V.; Piticescu, R.M.; Tarnița, D.N. Composite polymer for hybrid activity protective panel in microwave generation of composite Polytetrafluoroethylene-Rapana Thomasiana. Polymers 2021, 13, 2432. [CrossRef]

50. Allison, D.C.; McIntyre, J.A.; Ferro, A.; Brien, E.; Menendez, L.R. Bone grafting al- ternatives for cavitary defects in children. Curr. Orthop. Pract. 2013, 24, 267-279. [CrossRef]

51. Brack, R.; Amalu Emeka, H. A review of technology, materials and R\&D challenges of upper limb prosthesis for improved user. Suitability 2021, 23, 88-96.

52. Gautam, D.; Malhotra, R. Megaprosthesis versus Allograft Prosthesis Composite for massive skeletal defects. J. Clin. Orthop. Trauma 2018, 9, 63-80. [CrossRef]

53. Li, Y.; Tsai, L.F. The bone anchored prostheses for amputees-Historical development, current status, and future aspects. Biomaterials 2021, 273, 120836. [CrossRef]

54. Tarnita, D.; Boborelu, C.; Popa, D.; Tarnita, D.N. Design and Finite Element Analysis of a New Spherical Prosthesis-Elbow Joint Assembly. In New Advances in Mechanism and Machine Science. Mechanisms and Machine Science; Doroftei, I., Oprisan, C., Pisla, D., Lovasz, E., Eds.; Springer: Cham, Switzerland, 2018; Volume 57, pp. 127-135.

55. Huten, D.; Lambotte, G.P.J.-C. Techniques for filling tibiofemoral bone defects during revision total knee arthroplasty. Orthop. Traumatol. Surg. Res. 2021, 107, 102776. [CrossRef] 
56. Tarnita, D. Effects of malalignment angle on the contact stress of knee prosthesis components, using finite element method. Rom. J. Morphol. Embryol. 2017, 58, 831-836.

57. Tarnita, D.; Pisla, D.; Geonea, I.; Vaida, C.; Catana, M.; Tarnita, D.N. Static and Dynamic Analysis of Osteoarthritic and Orthotic Human Knee. J. Bionic. Eng. 2019, 16, 514-525. [CrossRef]

58. Axelrad, T.W.; Kakar, S.; Einhorn, T.A. New technologies for the enhancement of skeletal repair. Injury 2007, 38, 49-62. [CrossRef]

59. Williams, S.K.; Kleinert, L.B.; Hagen, K.M.; Clapper, D.L. Covalent modification of porous implants using extracellular matrix proteins to accelerate neovascularization. J. Biomed. Mater. Res. Part A 2006, 78, 59-65. [CrossRef] [PubMed]

60. Drosse, I.; Volkmer, E.; Capanna, R.; De Biase, P.; Mutschler, W.; Schieker, M. Tissue engineering for bone defect healing: An update on a multi-component approach. Injury 2008, 39, S9-S20. [CrossRef]

61. Silva, S.S.; Oliveira, M.B.; Mano, J.F.; Reis, R.L. Bio-inspired Aloe vera sponges for biomedical applications. Carbohydr. Polym. 2014, 112, 264-270. [CrossRef]

62. Silva, T.H.; Moreira-Silva, J.; Marques, A.L.P.; Domingues, A.; Bayon, Y.; Reis, R.L. Marine origin collagens and its potential applications. Mar. Drugs 2014, 12, 5881-5901. [CrossRef]

63. Lin, Z.; Solomon, K.L.; Zhang, X.; Pavlos, N.J.; Abel, T.; Willers, C.; Dai, K.; Xu, J.; Zheng, Q.; Zheng, M. In vitro evaluation of natural marine sponge collagen as a scaffold for bone tissue engineering. Int. J. Biol. Sci. 2011, 7, 968-977. [CrossRef]

64. Nandi, S.K.; Kundu, B.; Mahato, A.; Thakur, N.L.; Joardar, S.N.; Mandal, B.B. In vitro and in vivo evaluation of the marine sponge skeleton as a bone mimicking biomaterial. Integr. Biol. 2015, 7, 250-262. [CrossRef]

65. Best, S.M.; Porter, A.E.; Thian, E.S.; Huang, J. Bioceramics: Past, present and for the future. J. Eur. Ceram. Soc. 2008, 28, 1319-1327. [CrossRef]

66. Palmer, L.C.; Newcomb, C.J.; Kaltz, S.R.; Spoerke, E.D.; Stupp, S.I. Biomimetic systems for hydroxyapatite mineralization inspired by bone and enamel. Chem. Rev. 2008, 108, 4754-4783. [CrossRef] [PubMed]

67. Sopyan, I.; Mel, M.; Ramesh, S.; Khalid, K.A. Porous hydroxyapatite for artificial bone applications. Sci. Technol. Adv. Mater. 2007, 8, 116-123. [CrossRef]

68. Rocha, J.H.G.; Lemos, A.F.; Agathopoulos, S.; Kannan, S.; Valerio, P.; Ferreira, J.M.F. Hydrothermal growth of hydroxyapatite scaffolds from aragonitic cuttlefish bones. J. Biomed. Mater. Res. Part A 2006, 77, 160-168. [CrossRef]

69. Nandi, S.K.; Kundu, B.; Mukherjee, J.; Mahato, A.; Datta, S.; Balla, V.K. Converted marine coral hydroxyapatite implants with growth factors: In vivo bone re- generation. Mater. Sci. Eng. C 2015, 49, 816-823. [CrossRef]

70. Ozawa, M.; Satake, K.; Suzuki, R. Removal of aqueous chromium by fish bone waste originated hydroxyapatite. J. Mater. Sci. Lett. 2003, 22, 513-514. [CrossRef]

71. Huang, Y.-C.; Hsiao, P.-C.; Chai, H.-J. Hydroxyapatite extracted from fish scale: Effects on MG63 osteoblast-like cells. Ceram. Int. 2011, 37, 1825-1831. [CrossRef]

72. Hosoi, K.; Hashida, T.; Takahashi, H.; Yamasaki, N.; Korenaga, T. New processing technique for hydroxyapatite ceramics by the hydrothermal hot-pressing method. J. Am. Ceram. Soc. 1996, 79, 2771-2774. [CrossRef]

73. Hu, J.; Russell, J.J.; Ben-Nissan, B.; Vago, R. Production and analysis of hydroxyapatite from Australian corals via hydrothermal process. J. Mater. Sci. Lett. 2001, 20, 85-87. [CrossRef]

74. Yang, W.D.; Gomes, R.R., Jr.; Alicknavitch, M.; Farach-Carson, M.C.; Carson, D.D. Perlecan domain I promotes fibroblast growth factor 2 delivery in collagen I fibril scaffolds. Tissue Eng. 2005, 11, 76-89. [CrossRef]

75. Agbeboh, N.I.; Oladele, I.O.; Daramola, O.O.; Adediran, A.A.; Olasukanmi, O.O.; Tanimola, M.O. Environmentally sustainable processes for the synthesis of hydroxyapatite. Heliyon 2020, 6, e03765. [CrossRef] [PubMed]

76. Nayak, A.K. Hydroxyapatite synthesis methodologies: An overview. Int. J. Chem. T. Res. 2010, 2, 903-907.

77. Walsh, P.J.; Buchanan, F.J.; Dring, M.; Maggs, C.A.; Bell, S.; Walker, G.M. Low-pressure synthesis and characterization of hydroxyapatite derived from mineralize red algae. Chem. Eng. J. 2008, 137, 173-179. [CrossRef]

78. Neira, I.S.; Guitian, F.; Taniguchi, T.; Watanabe, T.; Yoshimura, M. Hydrothermal synthesis of hydroxyapatite whiskers with sharp faceted hexagonal morphology. J. Mater. Sci. 2008, 43, 2171-2178. [CrossRef]

79. Mobasherpour, I.; Soulati, H.M.; Kazemzadeh, A.; Zakeri, M. Synthesis of nanocrystalline hydroxyapatite by using precipitation method. J. Alloy. Compd. 2007, 430, 330-333. [CrossRef]

80. Pandharipande, S.L.; Sondawale, S.S. Review on the characterization methods of hydroxyapatite and its bio-composites. Int. J. Sci. Eng. Technol. Res. 2016, 5, 3410-3416.

81. Chen, B.H.; Chen, K.I.; Ho, M.L.; Chen, H.N.; Chen, W.C.; Wang, C.K. Synthesis of calcium phosphates and porous hydroxyapatite beads prepared by emulsion method. Mater. Chem. Phys. 2009, 113, 365-371. [CrossRef]

82. Shih, W.J.; Wang, M.C.; Hon, M.H. Morphology and crystallinity of the nanosized hydroxyapatite synthesized by hydrolysis using cetyltrimethylammonium bromide (CTAB) as a surfactant. J. Cryst. Growth 2005, 275, 2339-2344. [CrossRef]

83. Dagmara, M.; Biernat, K. Sobczak-Kupiec AStudies on sintering process of hydroxyapatite. Acta Biochim Pol. $2013,60,851-855$.

84. Guo, X.; Yan, H.; Zhao, S.; Zhang, L.; Li, Y.; Liang, X. Effect of calcining temperature on the particle size of hydroxyapatite synthesized by solid-state reaction at room temperature. Adv. Powder Technol. 2013, 24, 1034-1038. [CrossRef]

85. Savu, I.D.; Savu, S.V.; Benga, G.C. Thermal Runaway of the $\mathrm{BaCO}_{3}+\mathrm{Fe}_{2} \mathrm{O}_{3}$ homogenous mixture and mechanical alloys at the microwave heating. Adv. Mater. Res. 2014, 837, 185-189. [CrossRef]

86. Sunqing, Q.; Junxiu, D.; Guoxu, C. Wear and Friction Behaviour of $\mathrm{CaCO}_{3}$ Nanoparticles used as Additives in Lubricating Oils. Lubr. Sci. 2000, 12, 205-212. [CrossRef] 
87. Savu, I.D.; Savu, S.V.; Simion, D.; Sirbu, N.A.; Ciornei, M.; Ratiu, S.A. PP in 3D Printing-Technical and Economical Aspects. Mater. Plast. 2019, 56, 931-936. [CrossRef]

88. Menezes, R.R.; Souto, P.M.; Kiminami, R.H.G.A. Microwave fast sintering of ceramic materials. In Sintering of Ceramics-New Emerging Technologies; 2012; pp. 3-26.

89. Dondi, M.; Ercolani, G.; Marsigli, M.; Melandri, C.; Mingazzini, C. The chemical composition of porcelain stoneware tiles and its influence on microstructure and mechanical properties. InterCeram Int. Ceram. Rev. 1999, 48, 75-83.

90. The Toolbox Engineering. Specific Heat of Some Common Substances. Available online: engineeringtoolbox.com (accessed on 12 October 2021).

91. Porcelain-Density-Heat Capacity-Thermal Conductivity, Porcelain I Density, Heat Capacity, Thermal Conductivity. Available online: material-properties.org (accessed on 12 October 2021).

92. Marin, R.C.; Olei, A.B.; Stefan, I.; Savu, I.D.; Ghelsingher, C.D.; Savu, S.V.; David, A. Research microwave heating conditions of cordierite cylindrical shape for after treatment applications. Acta Technol. Napoc. Ser. Appl. Math. Mech. Eng. 2021, 64, 377-386.

93. Ionescu, A.; Savu, I.D.; Savu, S.V.; Coman, D. Computational features of flow modeling in nanostructured sensors. AIP Conf. Proc. 2009, 1117, 125-132. 